


\section{Nudging and pro-environmental behaviour}

Anne Sofie Elberg Nielsen, Henrik Sand, Pernille Sørensen, Mikael

Knutsson, Peter Martinsson, Emil Persson and Conny Wollbrant

TemaNord 2016:553 
Nudging and pro-environmental behaviour Anne Sofie Elberg Nielsen, Henrik Sand, Pernille Sørensen, Mikael Knutsson, Peter Martinsson,
Emil Persson and Conny Wollbrant

ISBN 978-92-893-4754-9 (PRINT)

ISBN $978-92-893-4755-6$ (PDF)

ISBN 978-92-893-4756-3 (EPUB)

http://dx.doi.org/10.6027/TN2016-553

TemaNord 2016:553

ISSN $0908-6692$

Standard: PDF/UA-1

ISO 14289-1

(c) Nordic Council of Ministers 2016

Layout: NMR

Print: Rosendahls

Printed in Denmark

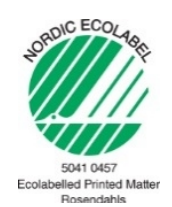

Although the Nordic Council of Ministers funded this publication, the contents do not necessarily reflect its views, policies or recommendations.

\section{Nordic co-operation}

Nordic co-operation is one of the world's most extensive forms of regional collaboration, involving Denmark, Finland, Iceland, Norway, Sweden, the Faroe Islands, Greenland, and Åland.

Nordic co-operation has firm traditions in politics, the economy, and culture. It plays an important role in European and international collaboration, and aims at creating a strong Nordic community in a strong Europe.

Nordic co-operation seeks to safeguard Nordic and regional interests and principles in the global community. Shared Nordic values help the region solidify its position as one of the world's most innovative and competitive. 


\section{Contents}

Preface.

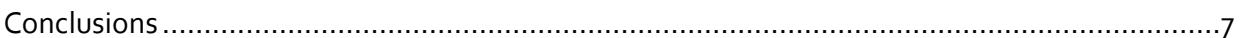

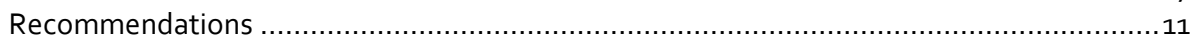

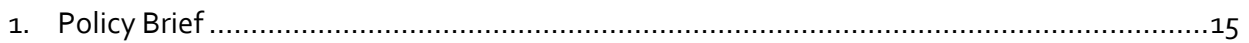

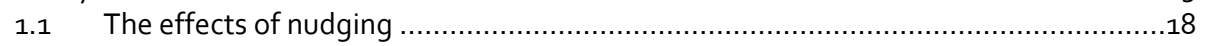

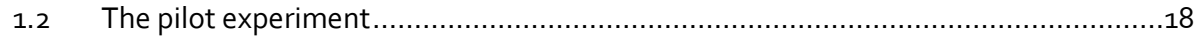

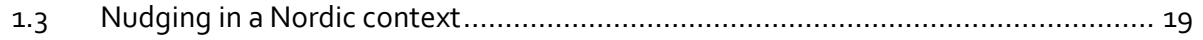

1.4 Analysing, designing and combining nudges .................................................. 20

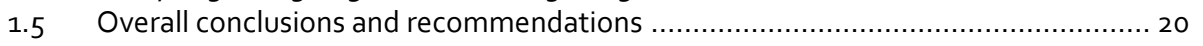

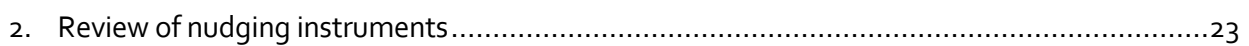

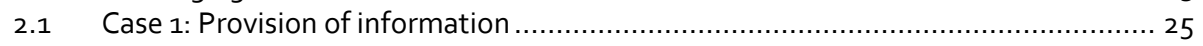

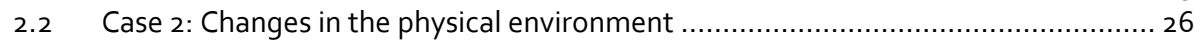

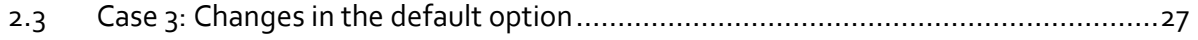

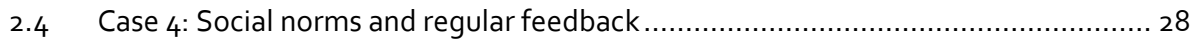

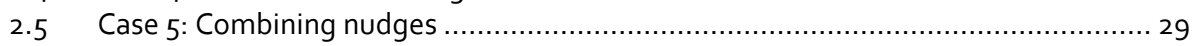

2.6 Comparing the four types of nudges: how often, where and

how are they used - what are the effects of nudging .........................................

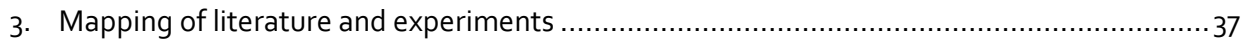

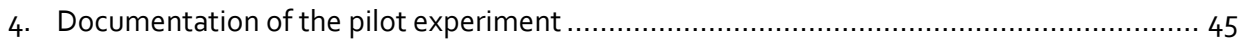

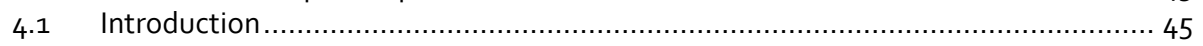

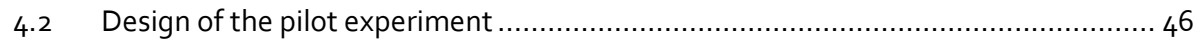

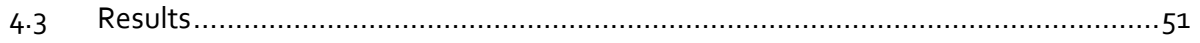

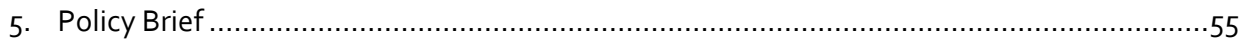

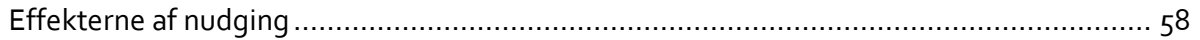

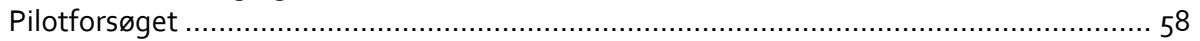

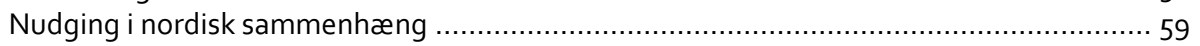

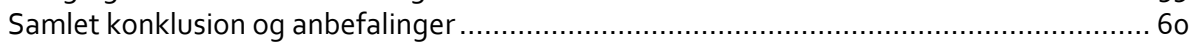

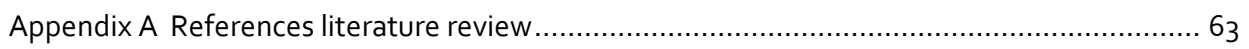

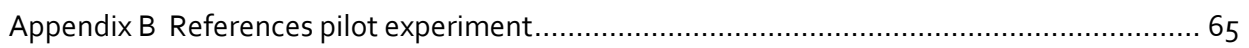





\section{Preface}

Over the past years nudging has become a mainstream set of tools in several environmental sectors including energy use, waste handling and resource efficiency. Nudges are a special set of policy instruments because they may not forbid actions or alter economic incentives significantly. As such, nudges may be used when legal or economic instruments, for any reason, cannot be used.

With this report we want to scrutinise the arguments and evidence for using nudging as an effective tool in environmental policy. The study is conducted by looking at experiences from implemented nudges as well as carrying out a pilot study. The results clearly show that nudges can alter behaviour in a more sustainable way. A relevant question for the future is how nudges can be combined with traditional policy instruments.

The report has been written by COWI with support from researchers from the Department of economics at University of Gothenburg. All results and conclusions are those of the authors.

October 2016

Fredrik Granath

Chairman of the Working Group on Environment and Economy under the Nordic Council of Ministers 



\section{Conclusions}

The key issue for a nudge is that it "...alters people's behaviour in a predictable way without forbidding any options or significantly changing their economic incentives...." (Thaler and Sunstein, 2008, p.6). The million-dollar question, however, is which of the nudges is the best? Unfortunately, there is no simple answer to that question although a considerable amount of research has been conducted in this field, but not always sufficiently systematically to draw evident conclusions. The key issue is to understand how individual's behaviour is affected by different nudges and to conduct large-scale field experiments to test different nudges against each other. An important issue here is to have enough time to allow for proper design, testing and execution of a field experiment. For example, van Bravel et al. (2013) suggest a minimum of 12 months.

In this study, we have conducted a literature review and a pilot experiment examining the impact of using nudging to influence donation behaviour in a Swedish supermarket. The literature review includes 20 different articles and reports on a total of 30 cases and experiments covering nudging in energy consumption, waste and resource efficiency plus four types of nudges: 1) Provision of information, 2) Changes in the physical environment, 3) Changes in the default option and 4) Use of social norms and regular feedback. With the exception of default options, the pilot experiment examines the influence of the same nudges on donation behaviour.

Overall, both the literature review and the pilot experiment find a strong case for using nudging to promote more environmentally friendly behaviour in energy consumption, waste and resource efficiency. This especially applies to:

- Providing real-time information by using, for instance, in-house smart meters to display energy usage and to provide transparency about the impact of current energy use and prices in order to reduce peak consumption (see case 1 on page 17).

- Making changes in the default options to ensure the uptake of green energy supply instead of conventional fossil-based energy by using a green default option for electricity consumption, thereby making the energy consumption more environmentally friendly (see case 3 on page in section 3.3). 
- Using social norms through peer comparisons to reduce energy consumption by comparing and displaying own and peer energy consumption patterns (see case 4 in section 3.4).

Common across these three examples of nudges are that they are suitable for policy making, because they:

- Are suitable for a large target group ranging from private individuals to private companies and public authorities.

- Have shown to be capable of delivering sizeable reductions in energy consumption and improved energy efficiency across several cases and experiments.

- Have the potential to be transferred to other resources such as resource use related to water and waste.

Changes in the physical environment are of particular focus within waste handling related to recycling and food waste accumulation, while no such examples have been reviewed within energy consumption and energy efficiency. With regard to waste handling, bins should be strategically placed and easy to find, and sorting not too demanding in terms of the number of sorting options.

Nudging using the provision of information is the most predominant type of nudge, often used in conjunction with changes in the default option. Providing credible and accessible information that reduces the complexity of choice is a promising tool to increase pro-environmental choices.

Another promising avenue is the use of changes in the default options, though these are almost exclusively applied to promote a reduction in energy consumption, to increase energy-efficient behaviour and to ensure the uptake of green energy supply instead of conventional fossil-based energy. The focus should be on situations where the consumers are making decisions regarding their energy supply.

The use of social norms has shown that offering peer comparisons in combination with information on individual consumption patterns can be an effective way of reducing resource use in the energy and water sectors. In the pilot experiment, social norms provided the largest impact on donation behaviour. The focus should be on situations where consumers have, or can have, information for their own usage and are able to benchmark this usage towards credible reference groups and encourage more energyefficient behaviour. Evidence from the pilot experiment suggests that a similar approach could be used for waste sorting and recycling. 
In our pilot field experiment, we compared the relative effects of three different types of nudges on donation behaviour. The results indicate that subtle interventions such as appealing to social norms or providing information affect environmentally friendly behaviour in the context of donations. An important question is how to generalise the findings so that they can be used for other environmental goods and in particular how to use the nudges for these goods. Based on existing literature together with the results from our field experiment and focus group interviews, our analysis seems to suggest that these types of nudge could play an important role in Nordic environmental policy, for example concerning energy use, transportation and waste and resource effectiveness. In addition, the literature review and focus group studies have indicated that the default option has a strong effect on behaviour, but there are limitations as to when it can be used since in many cases a natural default does not exist.

While some of the cases and experiments are from the Nordic countries and Europe, most are US-based regardless of the category of nudge applied. This study does not deal with the environmental regulatory framework in general and does not look into how nudging should be perceived in relation to existing environmental regulation. Since waste, resource efficiency and energy consumption are regulated differently in, for instance, the US compared to the Nordic countries, this has to be taken into consideration when building on experiences from non-Nordic countries.

There are examples of nudges in the waste area in Nordic countries that have had counterproductive effects such as reactions against further environmental regulation or avoiding fees on waste by illegal waste dumping (table 17, case 29). Nordic countries already experience a rather high degree of environmental regulation and nudging, as policy instruments would probably benefit from being carefully designed to fit into, and be complementary to, the existing regulatory framework.

Furthermore, human incentives and behaviour are, in a broad sense, expected to be the same and most of the cases and experiments reviewed in the literature study whether US-based or not - address environmental themes and challenges that are common to most developed countries. Therefore, there are reasons to believe that experience and lessons learned from the reviewed cases and experiments in this study can serve as a platform for further analysis and use of nudges in the Nordic countries.

Several of the nudges we discussed are straightforward to apply to waste sorting and recycling, and they could be used to reduce littering in public places. For example, provision of information and social norms are similar for waste sorting in the case of energy by providing information on the effects of not waste sorting, especially morality related information, and social norms by referring to waste sorting of for example neighbours. For waste sorting, we also believe that the physical environment can be an 
important nudge; bins should be strategically placed and easy to find, and sorting per se should not be too demanding in terms of number of sorting options.

For the choice of energy source, we suggest offering a default option with renewable energy, but also social norms with information about the energy sources used by others. Social norms have been shown to be able to reduce energy consumption successfully and are easily communicated with billing information. In addition, feedback in terms of an overview of past consumption as well as direct information, for example text messages when it is desirable not to consume more energy than absolutely necessary (during peak hours on cold days, for instance), and smart meters installed in households are promising directions for the future. Smart meters are particularly interesting, due to their potential for dynamic feedback on energy use and because they could be designed to incorporate aspects of all the three different nudges tested in our pilot field experiment. Information about energy consumption of appliances at the time of purchase is another tool that can guide people towards more energy efficient choices.

For transport, we suggest introducing carbon compensation for flying as the default option upon buying the ticket. We also think that social norms and the provision of information can be supportive in this context, where the former could relate to other people's propensity to compensate their emissions from flying or other people's emission levels related to their flights and the latter could be provision of information on the consequences of $\mathrm{CO}_{2}$ emissions. In other areas of transport, we suggest using the positive effect of information and social norms. It is important to motivate people to shift to more energy-efficient cars or alternatively fuelled cars, and to change modes of transport, for example to bicycles instead of cars. Again, information about the environmental consequences and social norms related to other people's behaviour are important nudges. One specific type of social norm is, for example, to link bicycling to fitness challenges where information about other people's cycling behaviour is provided.

Nudges related to information and physical environment are context-specific and should be developed and tested separately their individual effect. This is especially important where people are heterogeneous, meaning that for the same goods, different nudges might not have the same effect across different subgroups in society. This is one of the reasons why one should have clear prediction of how the nudge per se affect motivation and behaviour (see above discussion on the model by Bénabou and Tirole (2006) and Knutsson et al. (2016)).

Moreover, it is important to test nudges in both focus groups and pilot tests thoroughly before implementing them in large-scale field experiments. An important task when implementing a field experiment is to have clear treatments and a well-defined control. Each of the treatments should be clearly described to avoid confounded effects. Moreover, it is important to include a randomisation process that ensures that 
subjects are randomly assigned to treatments. An example is our experiment, where we applied cyclically changing treatments every 30 minutes, beginning with different treatments each of the four days and selecting similar days from the implementation to ensure that the characteristics of customers were as similar as possible. ${ }^{1}$

Overall, nudges are promising policy tools for environmental goods. Default options should be used when possible and they can be combined with each of the other nudge categories. In terms of research, more focus should be devoted to how to use social norms. Behaviour is usually characterised by conformism, which may lead to higher or lower levels of, for example, waste sorting and energy consumption, depending on whether the information provided is "higher" or "lower" than the individual decision maker's initially intended behaviour.

An important question for future research is therefore which reference group to use and what information to provide to ensure that the desire to conform offsets any private incentives not to do so. Since nudges are non-invasive, there is a risk that their effects do not last long enough to change habits. It is therefore important for future research to investigate the time paths of relative nudge effects. Some nudges may have a high initial effect on behaviour which, however, diminishes over time, while others may have a lower initial behavioural effect but over time contribute to a more robust effect and eventually be habit changing. The relative efficiency of each nudge will then depend on the relevant time horizon of the policy, and this area has still be to be explored.

\section{Recommendations}

Based on the literature review, the pilot experiment and the conclusions of this study, we are proposing the following recommendations to the policy makers and other relevant stakeholders in the Nordic countries.

First recommendation: The review of the nudging cases and experiments in this report shows several examples of nudges that have the potential for altering people's behaviour within energy consumption in particular, and having potential in the field of waste management and resource efficiency. In general, there is a need to further explore the potentials in a Nordic context through experiments that are more practical, policy development and the practical implementation of nudging instruments.

\footnotetext{
${ }^{1}$ For an excellent discussion on randomisation and econometrics of field experiment, see Duflo et al. (2008).
} 
Second recommendation: Policy makers and other stakeholders involved in developing nudging instruments for different environmental areas and goods should be aware of involving utility companies at the national level as they have end-user contact and provide tools and incentives for utilities to conduct pilot projects.

Special focus needs to be placed on the incentives of the utility companies and how the use of nudging will affect these. Providing real-time information will likely reduce peak consumption, green default options and the use of physical information with regard to waste handling, recycling will make the consumption more environmentally friendly, and peer-review reports will reduce the overall consumption. Nudging may thus - if successfully implemented - change and reduce the consumption patterns of the energy, water and waste services that the utilities sell to households, housing associations and companies. Given that this conflicts with the revenue stream of the utilities, they will look for alternatives to compensate for the potential drop in turnover. If the utilities are not bound to promote resource-efficient solutions to their customers and do not see any prospects in changing their business strategy, this will most likely be an impediment to the use of nudging. This issue can be handled by either forcing the utilities, compensating them, helping them to identify new business opportunities and revenue streams or setting up a bonus for those utilities, who achieve the greatest effect.

Public authorities could provide a toolbox and, if needed financial support to conduct pilot projects. Pilot projects could be designed so that the utilities can offer nudging (such as smart meters, green default options and peer comparisons) to a representative sample of user segments and compare the impact to a similar representative control group. Such user segments can be households, housing associations and companies.

Similar pilot projects can be introduced for facility managers of governmental, regional or municipal buildings. The nudges can potentially also be applied to the users of buildings, as their behaviour influences the consumption of energy.

Third recommendation: Use this report as a basis for organising workshops in each of the Nordic countries, where the relevant policy makers, public authorities and utility companies are invited to receive an introduction to nudging and the findings and conclusion of this report.

Fourth recommendation: The MEG group could engage in further exploration of nudging in the Nordic countries by assessing the results and impacts of pilot projects and highlighting lessons learned across the Nordic countries.

As a follow-up to this report, specific recommendations to MEG's further work in relation to nudging would be to: 
- Look further into how experiences from energy consumption and energy efficiency could serve as a platform not only for further investigation into implementing similar nudges in a Nordic context, but also for the potential in transferring experience to other utilities such as resource use related to water and waste. This can, for example, include smart meters (case 1), sizing (case 2), default options (case 3), social norms (case 4) or a combination (case 5).

- Select five experiments for further analysis to explore the aspects on which the literature review showed that there is little or lack of information and data. This analysis may include costs, user-segmentation, impact, effectiveness, gender issues and the possible interplay with other policy instruments. Experiments should be large-scale and allow for proper designing, testing and execution to test the impact of different nudges. A timeframe of 6-12 months is deemed necessary depending on the size and complexity of the nudges tested. Special focus should be given to the possibilities to use the experiments within energy consumption, waste or resource efficiency in a Nordic context.

- Select an area of relevance across the Nordic countries where there is a lack of impact using traditional policy instruments. This area could, for example, be energy efficiency in private households, or explore how nudging can be applied as an additional policy instrument. In addition, it is possible to add a socioeconomic analysis. 



\section{Policy Brief}

Nudging is about pushing people in a particular direction - getting them to make some specific decisions - without depriving them of the freedom to choose.

Different nudges alter people's behaviour in a predictable way without restricting choices or significantly changing economic incentives. ${ }^{2}$ Nudging can substitute or complement traditional policy instruments and offers a different way of achieving policy targets.

On behalf of the Environment and Economy Group (MEG) of the Nordic Council of Ministers, COWI A/S has conducted the study "Nudging in energy consumption, waste or resource efficiency". The purpose of the study is to identify how nudging has been used in concrete cases and experiments, its impacts and how nudging be can used as a policy instrument.

The study consists of two parts: a literature review conducted by COWI and a pilot experiment examining the impact of using nudging to influence donation behaviour in a Swedish supermarket conducted by Mikael Knutsson, Peter Martinsson, Emil Persson and Conny Wollbrant. In the study, we are reviewing and analysing four types of nudges:

- Provision of information.

- Changes in the physical environment.

- Use of a green default option.

- Use of social norms and regular feedback.

Major findings of the study - exploring four types of nudging.

Overall, the findings of the literature review and the results of the pilot experiment provide a strong case for using nudging to promote more environmentally friendly behaviour in energy consumption, waste and resource efficiency. From the literature examined, a wide range of evidence is available on how frequently nudging is applied, the prevalence of countries in which nudging have been tested, the scale of the cases and experiments, and the associated impact. Across all examined cases and experiments, 
most are US-based regardless of the category of nudge applied. It is, however, possible to find examples of all four categories of nudges in the Nordic countries. The literature review also shows that there is a predominance of cases and experiments where nudging is used to influence behavioural patterns in relation to energy consumption and energy efficiency (20 out of the 30 reviewed cases and experiments). The major findings are outlined below. Firstly, we provide an overview of each of the four types of nudging that we are analysing in this study. Secondly, the major findings from the pilot experiment are summed up. This is followed by the conclusions that can be drawn with respect to nudging in a Nordic context.

The findings in relation to the four types of nudges reviewed in this study are outlined below.

\section{Provision of information}

Nudging using the provision of information is the most predominant type of nudge, often used in conjunction with changes in the default option. Providing credible and accessible information that reduces the choice complexity is a promising tool to increase pro-environmental choices.

The literature review shows that most of the cases where information is used as nudging target energy consumption and energy efficiency.

The information-based nudges targeting energy consumption and energy efficiency also, in general, show both quantifiable and significant impacts (affecting energy consumption of $+1 \%$ to $-40 \%$, (see Table 4-1).

Moreover, there is the provision of real-time information. For instance, using in-house smart meters to display energy usage and provide transparency about the impact of current energy use and prices provides interesting results in terms of reducing energy consumption during peak hours (see cases 1 and 9 in Table $4^{-1}$ ).

\section{Changes in the physical environment}

Nudging through changes in the physical environment seems to be especially suitable to influence behaviour in relation to waste sorting, waste recycling and decrease in food waste. The literature review has not identified similar examples in energy consumption and energy efficiency.

The nudging cases and experiments that have been carried out in Nordic countries also show that nudging through changes in the physical environment are of particular focus in waste management, especially in targeting waste recycling and decrease of food waste.

The literature study has identified examples and experiments in Nordic countries where they used nudging in the form of changes in the physical environment. An experiment was conducted in order to reduce food waste in 52 Norwegian hotels (see case 25 in Table 4-3). The experiment entailed reducing the size of the used dishes, which resulted in the waste being reduced by almost $20 \%$. 
The Swedish case concerned waste recycling (see case 26 in Table 4-3) and used nudging as changes in the physical environment which, in the concrete case, meant introducing new sorting equipment for better segregation of waste sources. This nudge was applied together with provision of information and resulted in an increased food waste sorting of $44 \%-49 \%$.

\section{Changes in the default options}

Changing the default to a green option can, for example, be used to promote increased diffusion of green energy. When a consumer chooses the type of electrical supply required - green electricity from renewable energy or conventional electricity based on fossil fuels - the default is set to green electricity. The consumer must actively opt out of the green default, and actively opt in to conventional electricity supply. A number of examples and tests from Germany show that a very large percentage of consumers choose or remain in default in favour of green electricity (see examples in Table 3-4).

Changes in the default options are a promising type of nudge, though in the literature review this type of nudge is exclusively applied to promoting reductions in energy consumption and enhancing energy-efficient behaviour.

Except for one case where the change in default is used to nudge towards choosing a meat-free meal (see case 30 in Table 3-4).

\section{Use of social norms and regular feedback}

Social nudges in terms of using social norms through peer comparisons are interesting because this type of nudge is applied across both energy and water consumption as well as waste sorting.

Related to energy consumption, a range of studies in the US, UK and Ireland have documented that information provision in terms of social feedback combined with frequent information on current energy consumption patterns can reduce energy consumption by up to $7 \%$ (cases 1 and 5 to 9 in Table 4-1).

In water usage, the program WaterSmart is estimated to have reduced water use by $5 \%$ by a combination of feedback reports and peer comparisons (see case 27 in table 4-3).

An example from Norway concerns waste sorting, where a tax to promote waste sorting was introduced and, at the same time, social responsibility in relation to waste. The result was an increase in both quantity and quality of waste sorting (see Example 29 in Table 4-3). 
The literature review showed that three of the nudges are especially suitable for environmental policymaking: provision of information, changes in default options and using social norms - because all three of these are applicable to a large target group ranging from private individuals over private companies to public authorities. They have also proven to be capable of delivering sizeable reductions in energy consumption and improving energy efficiency across several cases and experiments. Finally, they have the potential to be applied to other policy areas such as resource use related to water and waste.

Changes in the physical environment are of particular focus within waste handling related to recycling and food waste accumulation, while no such examples have been reviewed within energy consumption and energy efficiency.

\subsection{The effects of nudging}

The effects of the cases and experiments of nudges in the reviewed literature vary from increases in energy consumption by $1 \%$ to decreases in peak energy consumption by up to $40 \%$. Labelling can increase the likelihood of choosing an energy-efficient product by up to 4.4 times, and a green default option can deliver a green energy choice $90 \%$ of the time. Potential effects are comparably large in waste and resource efficiency with plate size reductions potentially decreasing food waste by between 20 and $135 \%$.

\subsection{The pilot experiment}

The pilot experiment took place in a supermarket where reverse-vending machines for beverage containers with deposits refunded upon the return of the beverage containers. The beverage machine provides the consumer with the opportunity to donate the deposit instead of getting back the money. The three types of nudges used in the experiment are: (i) provision of information about the consequences of a donation, (ii) a change in the physical environment, and (iii) provision of information about social norms. The field experiment compares the relative effects of the three different types of nudges on donation behaviour. The interventions use nudges that neither change economic incentives nor forbid any type of behaviour.

In our pilot field experiment, we compared the relative effects of three different types of nudges on donation behaviour. Using this tailor-made field experiment, we find that each intervention has a positive but statistically insignificant effect on donations. The results thus indicate that subtle interventions such as appealing to social 
norms or providing information affect environmentally friendly behaviour in the context of donations. In addition, the literature review and focus group studies have indicated that default option has a strong effect on behaviour, but there are limitations as to when it can be used since, in many cases, a natural default does not exist. An analysis of the findings from the literature review and the results of the pilot experiment suggest that these subtle nudges may play an important role in Nordic environmental policy, for example concerning energy use, transportation and waste and resource effectiveness.

\subsection{Nudging in a Nordic context}

While some of the examined cases and experiments are from the Nordic Countries and Europe, the majority are from the US. This study does not deal with the environmental regulatory framework in general and does not look into how nudging should be perceived in relation to existing environmental regulation. Since waste, resource efficiency and energy consumption are regulated differently in, for instance, the US compared to the Nordic countries, this has to be taken into consideration when building on experiences from non-Nordic countries.

There are examples of nudges in the waste area in Nordic countries that have had counterproductive effects such as reactions against further environmental regulation or avoiding fees on waste by dumping waste in the nature (Table 17, case 29). Nordic countries already experience a rather high degree of environmental regulation and nudging used as policy instruments would probably benefit from being carefully designed to fit into and be complementary to the existing regulatory framework.

Human incentives and behaviour are broadly expected to be the same and most of the cases and experiments reviewed in the literature study - whether US-based or not - address environmental themes and challenges that are common to most countries in the developed part of the world. Therefore, there are reasons to believe that experience and lessons learned from the reviewed cases and experiments in this study can serve as a platform for further analysis and the use of nudges in Nordic countries. 


\subsection{Analysing, designing and combining nudges}

It is key to understand how an individual's behaviour is affected by different nudges and to conduct large-scale field experiments to differentially test nudges against each other and it is important to have enough time to allow for proper design, testing and execution of a field experiment as a basis for policy design.

The literature review identified a lack of information about how different types of nudging instruments interact with or complement other, more traditional, policy instruments. The results of the literature review also suggest that nudging in the form of information, in combination with changes in the physical environment, is very contextsensitive. This type of nudging should be developed and tested in relation to the concrete consumer area to have an effect on behavior. The literature review also shows that, to achieve success in nudging in terms of promoting environmentally friendly behavior, it is very important to investigate whether nudging will counteract the existing policy. The literature review did not provide any substantial information on how nudging should target different segments of consumers to achieve the most effective outcome. For instance, with respect to gender, there is little evidence on how gender influences the impact of nudges. Therefore, costs, gender and interaction with other policy instruments are interesting topics for further study towards the design of effective nudging.

\subsection{Overall conclusions and recommendations}

Overall, both the findings of the literature review and the pilot experiment support a strong case for using nudging to promote more environmentally friendly behaviour in energy consumption, waste and resource efficiency.

Several of the nudges we discussed are straightforward to apply to waste sorting and recycling. Nudging tools could be used to reduce littering in public places. In particular, changes in the physical environment have offered good results, both in relation to increasing the quantity and quality of waste sorting and waste recycling, as well as reducing food waste. Social nudges in terms of using social norms through the provision of information and peer comparisons have also shown results in relation to both waste sorting and water consumption. For the choice of energy source, we suggest offering a default option with renewable energy, but also social norms with information about the energy sources used by others. Smart meters are particularly interesting, due to their potential for dynamic feedback on energy use and because this nudge could be successful in relation to water consumption. In the transportation sector, introducing a default option of 
carbon compensation for flying when buying the ticket could be a successful nudge. In general, information about the environmental consequences and social norms related to other people's behaviour are important nudges.

Based on the literature review, the pilot experiment and the conclusions of this study, we are proposing the following recommendations to the policy makers and other relevant stakeholders in Nordic countries.

First recommendation: The review of the nudging cases and experiments in this report shows several examples of nudges that have the potential for altering people's behaviour within energy consumption in particular, and offer potential for the field of waste management and resource efficiency. In general, there is a need for further exploring the potentials in a Nordic context through further practical experiments, policy development and the practical implementation of nudging instruments.

Second recommendation: Policy makers and other stakeholders involved in developing environmental policy and regulation including nudging instruments for different environmental areas and goods should be aware of involving utility companies on a national level as they have end-user contact. Policy makers could also provide tools and incentives for utilities to conduct pilot projects.

Third recommendation: Use this report as a basis for organising workshops in each of the Nordic countries, where the relevant policy makers, public authorities and utility companies are invited to receive an introduction to nudging and the findings and conclusion of this report.

Fourth recommendation: The MEG group could engage in further exploration of nudging in the Nordic countries by assessing the results and impacts of pilot projects and highlighting lessons learned across the Nordic countries. More specifically MEG could:

- Look more into how experiences from energy consumption and energy efficiency could serve as a platform, not only for further investigation into implementing similar nudges in a Nordic context, but also for the potential in transferring experience to other utilities such as resource use related to water and waste.

- Select five experiments for further analysis to explore the aspects on which the literature review showed that there is little or no information and data. This analysis may include costs, user-segmentation, impact, effectiveness, gender issues and the possible interplay with other policy instruments.

- Select an area of relevance across the Nordic countries where there is a lack of impact using traditional policy instruments. In addition, consider adding a socioeconomic analysis. 



\section{Review of nudging instruments}

Environmental challenges are increasingly addressed politically. To implement policies, several policy instruments are used. The effectiveness of the instruments varies, and knowing how they work is of great importance in order to achieve the intended outcomes. Nudging can be regarded as a policy instrument that, when designed properly, can help ensure or improve the implementation of environmental legislation and regulations or even replace traditional environmental policies.

In some instances, nudges such as information campaigns that challenge you to reduce your consumption patterns may stand alone, while other nudges, such as requiring all goods to be labelled with their energy efficiency performance, may depend on the existence of other legislation that obliges the use of energy efficiency labelling on a certain range of goods.

Nudges can thus act as both a substitute and a complement to traditional policy instruments such as taxes and technical legislation, and offer a different way of achieving policy objectives.

Nudging is a way of influencing people's choices without limiting the choice set. Nudges thus alter people's behaviour in a predictable way without restricting choices or significantly changing economic incentives. ${ }^{3}$ Nudging can be applied in different phases of the life cycle associated with resource consumption, from the decision to purchase a certain good or service to the use of that good or service and, finally, when making the end-of-life waste management decision.

COWI A/S has conducted this literature review on behalf of The Environment and Economy Group (MEG). The review focuses on ways of increasing environmentally friendly behaviour using the four different categories of nudges:

- Provision of information.

- Changes in the physical environment.

- Use of a green default.

- Use of social norms and regular feedback.

3 Hausman \& Welch (2010). Journal of Political Philosophy, vol. 18, Thaler. 
Based on 20 papers consisting of both Nordic and international literature, this literature review focused on a total of 30 cases and experiments deploying nudges within energy consumption, waste and resource efficiency. ${ }^{4}$ We have selected and reviewed literature with an emphasis on providing a context that can be transferred to and used for policy development in the Nordic countries.

In the review of the cases and experiments, we have focused on factors related to issues such as their policy theme, success, scale, location, target group, the price of the nudge and, if possible, gender issues. We have synthesised cases and experiments according to these issues and mapped them in the tables included in sections 3 and 4 . In addition, we have provided an accompanying Excel spreadsheet containing a full set of gross and net list literature and the associated tabular mapping of each paper.

Table 1 below illustrates the types of nudge with examples of the themes and policy areas that each type of nudge addresses.

Table 1: Different examples of nudges

\begin{tabular}{|c|c|}
\hline Type of nudge & Examples of nudges \\
\hline Provision of information & $\begin{array}{l}\text { Information on energy use of e.g. household or office units. } \\
\text { Real-time displays providing current information on energy consumption and prices, either } \\
\text { through green lights or information on prices and quantities. } \\
\text { Information on current energy prices through green lights system. } \\
\text { Energy labels on housing, household appliances and products. } \\
\text { Information campaigns to households. } \\
\text { Social media campaigns. }\end{array}$ \\
\hline $\begin{array}{l}\text { Changes in the physical } \\
\text { environment }\end{array}$ & $\begin{array}{l}\text { Change in waste-sorting equipment. } \\
\text { Changing the plate size. }\end{array}$ \\
\hline $\begin{array}{l}\text { Changes in the default } \\
\text { options }\end{array}$ & $\begin{array}{l}\text { Change in default for } \mathrm{CO}_{2} \text { offsetting. } \\
\text { Change in default temperature in offices. } \\
\text { Shutdown of offices during certain periods. } \\
\text { Change in default to accept installation of smart-grid technology. } \\
\text { Green electricity default. } \\
\text { Change in default menu to a meat-free version. }\end{array}$ \\
\hline $\begin{array}{l}\text { Use of social norms and } \\
\text { regular feedback }\end{array}$ & $\begin{array}{l}\text { Feedback on energy and water usage compared to social reference group, such as similar } \\
\text { neighbours. } \\
\text { Information campaign focusing on social responsibility to sort waste. }\end{array}$ \\
\hline
\end{tabular}

\footnotetext{
4 The reference list of the 20 papers that have been analysed in depth is in appendix A. The litteratur review is based on an initial screening of 83 articles and papers of which 20 papers were selected for further analysis. The selection criteria were policy focus, type of experiment, focus of the study: energy consumption, waste management, resource use. The reader can get access to the excel file with all 83 articles and papers reviewed and ranked at the COWI website: http://www.cowi.com/nudgingtowardsenvironmentallyfriendlybehavior
} 
Section 4 of this report comprises a full list of the reviewed cases and experiments.

The following subsections provide case examples that describe how the four different types of nudges are used in practice.

\subsection{Case 1: Provision of information}

With limited or imperfect information about the costs of using energy-consuming appliances, it can be difficult for individuals to fully comprehend the consequences of their actions, such as for instance choosing between two different washing machines, or using the washing machine at different periods of the day. Providing updated information in the form of, for example, in-house displays can be one way to overcome this information barrier, by both providing a constant reminder of the energy consumption and by providing a learning tool by which individuals gradually learn to distinguish between the energy use of different appliances.

\section{Why does real-time information reduce energy consumption?}

Using a randomised-control experiment, 65 residential households in a condominium complex in Honolulu, US were assigned to one control group and two treatment groups. Both treatment groups had an in-house display of energy usage installed in their homes; the first group for the full go days of the experiment, the other treatment group for a period of 60 days. The control group did not receive any in-house displays. The in-house displays provide households with real-time information on their electricity consumption.

The study finds that providing real-time information through in-house displays reduces the average household electricity consumption by up to $11 \%$, depending on the time of the day. Electricity consumption reductions occur when people are likely to be home, i.e. in the morning and in the evening, but not at other times of the day. The effect diminishes over time, as displays are removed and households get accustomed to having the available information at hand. The study supports the hypothesis that the reduction in energy usage is primarily driven by a learning effect and, to a lesser extent, the effect of having a constant reminder of energy usage - the so-called saliency effect. This has some importance given that the predominance of a learning effect would advocate for policy initiatives that target information outreach to energy users. This could be in the form of, for instance, information campaigns or the labelling of energy-consuming goods and services.

Lynham, J., Nitta, K., Saijo, T., Tatui, N (2016). Why does real-time information reduce energy consumption? Energy Economics 54 . 
As shown in Table 6, the use of real-time information has the potential to reduce energy consumption in peak consumption hours substantially (mornings and evenings), while at the same time educating individuals about the energy efficiency of different products and increasing the potential impact of other nudges such as energy labelling. Real-time information can be provided by private utilities in cooperation with public authorities to ensure a targeted effort that also takes into account the synergies that can be expected between different forms of nudging using provision of information. This includes those synergies expected to exist between real-time information on energy use and the use of labelling on energy-consuming household appliances. See also cases 1 and 10 in Section 4.

\subsection{Case 2: Changes in the physical environment}

Food consumption and waste is a large contributor to environmental and health issues such as climate change, land-use change and high obesity rates. Table 7 shows that a simple nudge such as decreasing the plate size may hold substantial potential in reducing both the amount of food consumed and that is wasted, which can have significant environmental and economic importance for both private, commercial and public stakeholders.

\section{Reducing Food Waste: The effect of changing the plate size}

An experiment was conducted between 1 July and 15 August 2012 when 52 Norwegian hotels were tested with two nudge treatments. Out of the 52 hotels, seven were in the control group.

In the first experiment, the plate size was decreased from 24 to $21 \mathrm{~cm}$. Reducing the plate size was found to reduce food waste by $19.5 \%$ compared to the control group.

In the second experiment, the plate size was reduced and a social cue suggesting that the buffet could be visited several times was displayed on a sign at the buffet. Combining a reduction in the plate size with a social norm led to a reduction in food waste of $20.5 \%$.

Results suggest that reducing the plate size by $1 \mathrm{~cm}$ can lead to a reduction in food waste of $2.5 \mathrm{~kg}$, which is a reduction in food waste of approximately $7.4 \%$.

Kallbekken et al. (2012), Bridging the Energy Efficiency Gap: A Field Experiment on Lifetime Energy Costs and Household Appliances, Journal of Consumer Policy. 
Public authorities using an information campaign to highlight the impact of a given nudge to relevant private and public stakeholders can promote nudges that use changes in the physical environment. In the case of changing the plate size, this could be in the form of public authorities engaging private individuals and private companies such as canteens, restaurants etc. offering dining solutions to reduce their plate size, by providing targeted information that showcases the expected gains in the form of e.g. expected weight loss, expected savings and the like.

\subsection{Case 3: Changes in the default option}

Default options refer to what happens when you do nothing. Since most people are subject to inertia and do not get around to changing defaults, changing the option that represents the default towards a more environmentally friendly one can be a powerful nudging instrument. Table 8 shows one example of the impact of setting a green default.

Since they preserve the freedom of choice and are likely to require management efforts similar to those applied in connection with conventional solutions, green defaults may require very little to implement compared to mandatory regulation in the form of mandatory and regulatory policies. Green defaults should be of particular focus in areas where environmental impacts are large and costs to consumers low, and they are deemed to have immense potential within the utility sector in particular.

\section{Green Defaults: Information presentation and pro-environmental behaviour}

Two natural experiments were conducted to see how a green default would affect electricity consumption.

In the first experiment, 2,500 inhabitants of Schönau had their default option changed from a "grey default" to a "green default." Eight years after the opening of the electricity market in Schönau (1998-2006), nearly every customer remained with the green default.

In the second experiment, Energiedienst $\mathrm{GmbH}$, a company supplying a grid area in southern Germany diversified its services offering three new tariffs where previously there had only been one. Letters were mailed to 150,000 private and business customers offering the opportunity to change their default option. Customers wishing to be supplied with the green tariff did not need to respond. The green tariff was slightly cheaper than the previous tariff offered by the company. The other two options were a grey, less expensive tariff (approx. $8 \%$ cheaper), and a more costly green tariff (approx. $23 \%$ more expensive, including a higher share of electricity generated from green facilities). Customers preferring one of these two alternative tariffs were required to reply. Two months after the request was sent, $4.3 \%$ of the customers had decided to switch to the cheapest tariff, less than $1 \%$ had switched to the premium-priced green tariff, and $7 \%$ reacted by switching to a different supplier. Around $94 \%$ of the customers remained with the default option. 
The natural experiments were supported by a laboratory experiment examining the willingness to pay for green energy supply. Overall, the findings support the hypothesis that once people have accepted a green default, they are very reluctant to move away from it, or require considerable monetary compensation to do so.

Pichert \& Katsikopoulos (2008), Green Defaults: Information Presentation and Pro-Environmental Behaviour, Journal of Environmental Psychology.

\subsection{Case 4: Social norms and regular feedback}

Table 9 presents an example of nudging using peer comparison reports to reduce energy consumption.

\section{Evidence from Two Large Field Experiments that Peer Comparison Feedback can reduce Residential Energy Usage}

Data from approximately 159,000 households were collected from two large-scale, random-assignment field experiments conducted by utility companies providing electricity and natural gas (the Sacramento Municipal Utility District (SMUD)) and electricity and natural gas (Puget Sound Energy (PSE)), in partnership with a private company, Positive Energy/power. The households received monthly or quarterly mailed peer feedback reports comparing their domestic electricity and natural gas consumption to their own prior usage and the usage of nearby similar-sized households. Bar charts comparing recent electricity use with comparable and "efficient" peers, twelve-month peer review, personal historical comparison and targeted energy efficiency advice were provided.

Households receiving the reports made significant and lasting reductions in their energy consumption. The effects of the report continue to be strong 7-12 months after the households began to receive reports. Households with larger pre-treatment consumption made larger cuts. Households with lower pre-treatment usage increased their energy use. To circumvent this, reports could be targeted to include only households where this "boomerang effect" is not expected to be present.

Ayres et al. (2012), Evidence from Two Large Field Experiments that Peer Comparison Feedback Can Reduce Residential Energy Usage, Journal of Law and Economic Organisation.

As is evident from Table 9 using social norms through peer review may provide lasting reductions in energy consumption in households. Given that similar effects are found 
for public offices, see case 5 , the peer review report poses an encouraging tool for reducing energy consumption across a broad group of private and public actors, where reports can quite easily and with relatively little effort (e.g. e-mails or social media), be distributed to the relevant actors.

One caveat should be noted when using peer comparisons. It is important to consider carefully how information is elicited. Several studies have found that, while aboveaverage energy consumers significantly decrease their energy use, below-average consumers may increase their energy use.

In addition, individuals with strong environmental ideologies primarily related to overly strong environmental regulation might respond to information dissemination with protest behaviour thus increasing their energy use. The latter effect, termed the "boomerang effect", may call for targeting information only to expected above-average consumers, or coupling the information with not only normative, but also conjunctive messages, e.g. in the form of unhappy "emoticons." Receiving a happy emoticon has been shown to remove the boomerang effect for below-average consumers.

\subsection{Case 5: Combining nudges}

In many instances, different nudges are used in combination and with other policy instruments to achieve a certain goal. A prime example is the UK government introducing a target of reducing $\mathrm{CO}_{2}$ emissions from the estate by $10 \%$ between May 2010 and May 2011, as described in Table 10.

Using Social Norms, Competition and changing defaults to Reduce Carbon Emissions in the UK central government office estate

To demonstrate the commitment to reducing carbon emissions, a goal was set that central government office estate should reduce emissions by $10 \%$ between May 2010 and May 2011.

To fulfil this goal, a range of initiatives were implemented. These included drawing on changing in the defaults for lighting, heating, and encouraging behavioural change through social norms and competition. The initiative thus included nudging through the provision of information, changes in default options and the use of social norms. Initiatives included:

- Changing defaults when heating and cooling systems were active.

- Changing default temperatures.

- Shutdown of buildings during quiet periods.

- Monthly performance tables showing progress.

- Review of departmental performance by the Cabinet Secretary. 
- Real-time displays, online reports of energy consumption.

- Cross-departmental competitions each month. Details of how savings were achieved were distributed.

- The goal of a $10 \%$ reduction in $\mathrm{CO}_{2}$ emissions was reached within the one-year period.

The Behavioural Insight Team (2011). Behaviour Change and Energy Use.

The case highlights the potential in using nudging to reduce energy consumption substantially within a very short timeframe. Furthermore, the reduction occurred in public offices, in which the private incentive of each worker to reduce energy consumption is assumed to be more limited compared to the incentive for reducing energy consumption in households. Achieving only an incremental share of similar reductions across Nordic private and public offices as well as households would amount to a substantial share of the current energy consumption.

\subsection{Comparing the four types of nudges: how often, where and how are they used - what are the effects of nudging}

An initial finding from the literature review and shown in Table 3.7 below is that the provision of information is the most common nudge applied, whereas changes in the physical environment, changes in the default option and the use of social norms and regular feedback are used with more or less the same frequency.

In a similar vein, the impact of using the different nudges shows considerable variation across type of nudge and theme related to energy consumption, energy efficiency and waste and resource efficiency. The effect varies from increases in the energy consumption by $1 \%$ to decreases in peak energy consumption by up to $40 \%$, whereas labelling can increase the likelihood of choosing an energy-efficient product up to 4.4 times, and green default can deliver a green energy choice $90 \%$ of the time.

The potential effects are relatively significant within waste and resource efficiency, with plate size reduction potentially decreasing food waste by between 20 and $135 \%$.

The gross variety across the examined cases and experiments should be seen in relation to the context of the different cases and experiments. Some experiments are conducted on the national level to a large part of the population, while other cases are much more restricted, such as a recycling experiment examine the waste behaviour of the users of a restroom. 
Table 2: Overview of nudging experience from literature review

\begin{tabular}{|c|c|c|c|c|}
\hline Topic & $\begin{array}{l}\text { Provision of infor- } \\
\text { mation }\end{array}$ & $\begin{array}{l}\text { Changes in the } \\
\text { physical environ- } \\
\text { ment }\end{array}$ & $\begin{array}{l}\text { Changes in the de- } \\
\text { fault option }\end{array}$ & $\begin{array}{l}\text { Use of social norms } \\
\text { and regular feed- } \\
\text { back }\end{array}$ \\
\hline $\begin{array}{l}\text { Number of times } \\
\text { used }\end{array}$ & 22 & 5 & 8 & 7 \\
\hline $\begin{array}{l}\text { Decrease in energy } \\
\text { consumption }\end{array}$ & $+1 \%$ to $-40 \%$ & NA & NA & $+1 \%$ to $-10 \%$ \\
\hline $\begin{array}{l}\text { Increase in the likeli- } \\
\text { hood of choosing en- } \\
\text { ergy-efficient options }\end{array}$ & $\begin{array}{l}5 \% \text { to } 4 \cdot 4 \text {. times } \\
\text { more likely }\end{array}$ & NA & $\begin{array}{l}\text { Approximately } 90 \% \\
\text { stay with green de- } \\
\text { fault }\end{array}$ & NA \\
\hline $\begin{array}{l}\text { Decrease in waste } \\
\text { and increase in re- } \\
\text { source efficiency }\end{array}$ & Unknown to $-5 \%$ & $-19.5 \%$ to $-135 \%$ & $\begin{array}{l}\text { Around } 100 \% \text { in- } \\
\text { crease in the likeli- } \\
\text { hood of choosing } \\
\text { sustainable food } \\
\text { choices }\end{array}$ & NA \\
\hline Average scale & $\begin{array}{l}65 \text { households to } 55 \\
\text { million users }\end{array}$ & $\begin{array}{l}\text { Users of one re- } \\
\text { stroom to } 320 \text { house- } \\
\text { holds }\end{array}$ & $\begin{array}{l}240 \text { conference par- } \\
\text { ticipants to } 150,000 \\
\text { electricity consumers }\end{array}$ & $\begin{array}{l}\text { Guests at } 52 \text { hotels to } \\
\text { residential water us- } \\
\text { ers across the U.S. }\end{array}$ \\
\hline
\end{tabular}

Looking across the different categories of nudges in the reviewed literature reveals differences in the areas where nudges are most commonly applied: see Table 12 and Table 13.

Table 3: Prevalence of the different types of nudges across resource use

\begin{tabular}{l|r|r|r|r|}
\hline Topic & $\begin{array}{r}\text { Provision of infor- } \\
\text { mation }\end{array}$ & $\begin{array}{r}\text { Changes in the } \\
\text { physical environ- } \\
\text { ment }\end{array}$ & $\begin{array}{r}\text { Changes in the de- } \\
\text { fault options }\end{array}$ & $\begin{array}{r}\text { Use of social norms } \\
\text { and regular feed- } \\
\text { back }\end{array}$ \\
\hline Energy consumption & 10 & 0 & 4 & 5 \\
Energy efficiency & 6 & 0 & 2 & 0 \\
Waste & 4 & 4 & 0 & 0 \\
Resource efficiency & 2 & 1 & 1 & 1 \\
\hline
\end{tabular}

Provision of information is the most common type of nudge used across all areas of resource use and is often combined with the use of social norms, while the use of default options are almost exclusively applied to promote a reduction in energy consumption and energy-efficient behaviour.

On the other hand, using changes in the physical environment is common within waste generation and recycling, although no such examples exist within energy usage 
and efficiency. The prevalence of the different types of nudges also reflects the different concrete examples assessed in the literature.

From Table 12 it is evident that there are few examples of changes in the physical environment. Such examples are restricted to changes in the waste sorting system and a change in the plate size. There are several examples of nudges using the provision of information. They range from national or global social media information campaigns and labelling of product groups to small-scale nudges using different variants of smart meters to provide real-time information to households or office units.

Across all examined cases and experiments, most are US-based regardless of the category of nudge applied. It is, however, possible to find examples of all four categories of nudges in the Nordic countries.

Table 4: Overview of different categories of nudges according to theme and location

\begin{tabular}{|c|c|c|c|c|}
\hline Topic & $\begin{array}{l}\text { Provision of } \\
\text { information }\end{array}$ & $\begin{array}{l}\text { Changes in the } \\
\text { physical environ- } \\
\text { ment }\end{array}$ & $\begin{array}{l}\text { Changes in the de- } \\
\text { fault option }\end{array}$ & $\begin{array}{l}\text { Use of social norms } \\
\text { and regular feed- } \\
\text { back }\end{array}$ \\
\hline $\begin{array}{l}\text { Environmental policy } \\
\text { theme }\end{array}$ & $\begin{array}{l}\text { Predominantly } \\
\text { within energy effi- } \\
\text { ciency and energy } \\
\text { consumption, but } \\
\text { also a few examples } \\
\text { within water use and } \\
\text { waste }\end{array}$ & $\begin{array}{l}\text { Examples within } \\
\text { waste generation } \\
\text { and recycling }\end{array}$ & $\begin{array}{l}\text { Examples exclusively } \\
\text { within energy effi- } \\
\text { ciency and energy } \\
\text { consumption }\end{array}$ & $\begin{array}{l}\text { Predominantly } \\
\text { within energy and } \\
\text { waste, but water us- } \\
\text { age also examined }\end{array}$ \\
\hline Country & $\begin{array}{l}\text { A number of exam- } \\
\text { ples from the US and } \\
\text { the UK, a few Euro- } \\
\text { pean-based ones }\end{array}$ & $\begin{array}{l}\text { Examples from both } \\
\text { Nordic countries and } \\
\text { the US }\end{array}$ & $\begin{array}{l}\text { Examples spread } \\
\text { across a wide set of } \\
\text { countries }\end{array}$ & $\begin{array}{l}\text { Examples predomi- } \\
\text { nantly US-based, a } \\
\text { few European-based } \\
\text { ones }\end{array}$ \\
\hline $\begin{array}{l}\text { Used in conjunction } \\
\text { with }\end{array}$ & $\begin{array}{l}\text { Commonly employed } \\
\text { in conjunction with } \\
\text { social norms and reg- } \\
\text { ular feedback and, to } \\
\text { a lesser degree, be- } \\
\text { cause of changes in } \\
\text { the physical environ- } \\
\text { ment }\end{array}$ & $\begin{array}{l}\text { Sometimes em- } \\
\text { ployed together with } \\
\text { provision of infor- } \\
\text { mation and social } \\
\text { norms and regular } \\
\text { feedback }\end{array}$ & $\begin{array}{l}\text { Sometimes em- } \\
\text { ployed with provision } \\
\text { of information }\end{array}$ & $\begin{array}{l}\text { Commonly employed } \\
\text { together with provi- } \\
\text { sion of information }\end{array}$ \\
\hline
\end{tabular}


Table 14 breaks down the different categories of nudges into their maturity, different target goods and groups, as well as factors related to the cost of use and gender issues. The table shows a clear diversification in the maturity of the different categories of nudges. Using provision of information is a very common approach to promote environmental behaviour, which is applied across the different resource uses. In comparison, we have found a small set of examples for changes in the default option and changes in the physical environment.

Most nudges have been applied to private consumption such as private household consumption of energy and water, and have thus primarily been inherently targeted to private consumers. In contrast, the number of agents likely to push for the use of different nudges spans a broader range of actors. Nudging may be part of a public regulatory toolbox, but semi-private and private agents such as utility companies, NGOs and private companies may be also push for and use nudging to promote environmentally friendly behaviour and goods.

In the literature reviewed, there is generally little mention of the costs of designing, implementing and managing nudging instruments. Equally, very little information is provided about potential gender diversities and their use and response to nudging, marking an obvious area for research for future studies. 
Table 5: Overview of different categories of nudges according to maturity, target group and cost

\begin{tabular}{|c|c|c|c|c|}
\hline Topic & $\begin{array}{l}\text { Provision of infor- } \\
\text { mation }\end{array}$ & $\begin{array}{l}\text { Changes in the } \\
\text { physical environ- } \\
\text { ment }\end{array}$ & $\begin{array}{l}\text { Changes in the de- } \\
\text { fault option }\end{array}$ & $\begin{array}{l}\text { Use of social norms } \\
\text { and regular feed- } \\
\text { back }\end{array}$ \\
\hline $\begin{array}{l}\text { Maturity - how often } \\
\text { is the nudge used? }\end{array}$ & Very commonly used & $\begin{array}{l}\text { A number of exam- } \\
\text { ples exist primarily } \\
\text { within waste genera- } \\
\text { tion and collection }\end{array}$ & $\begin{array}{l}\text { A number of exam- } \\
\text { ples exist }\end{array}$ & $\begin{array}{l}\text { A number of exam- } \\
\text { ples exist particularly } \\
\text { within household re- } \\
\text { source use }\end{array}$ \\
\hline $\begin{array}{l}\text { Where have the } \\
\text { nudges been ap- } \\
\text { plied? }\end{array}$ & $\begin{array}{l}\text { Private consumption } \\
\text { goods and services }\end{array}$ & $\begin{array}{l}\text { Private consumption } \\
\text { goods and services }\end{array}$ & $\begin{array}{l}\text { Private consumption } \\
\text { goods and services }\end{array}$ & $\begin{array}{l}\text { Private consumption } \\
\text { goods and services }\end{array}$ \\
\hline $\begin{array}{l}\text { Where can the nudge } \\
\text { be applied? }\end{array}$ & $\begin{array}{l}\text { In principle suitable } \\
\text { for all types of goods } \\
\text { and services }\end{array}$ & $\begin{array}{l}\text { Most suitable for pri- } \\
\text { vate consumption } \\
\text { goods and services, } \\
\text { but could also be ap- } \\
\text { plied to public ser- } \\
\text { vices }\end{array}$ & $\begin{array}{l}\text { In principle suitable } \\
\text { for all types of goods } \\
\text { and services }\end{array}$ & $\begin{array}{l}\text { In principle suitable } \\
\text { for all types of goods } \\
\text { and services }\end{array}$ \\
\hline $\begin{array}{l}\text { Reviewed target } \\
\text { group }\end{array}$ & $\begin{array}{l}\text { Public authorities } \\
\text { Private consumers }\end{array}$ & $\begin{array}{l}\text { Private consumer } \\
\text { Private companies }\end{array}$ & $\begin{array}{l}\text { Public authorities } \\
\text { Private consumers }\end{array}$ & $\begin{array}{l}\text { Public authorities } \\
\text { Private consumers }\end{array}$ \\
\hline $\begin{array}{l}\text { Potential target } \\
\text { group }\end{array}$ & $\begin{array}{l}\text { Public authorities } \\
\text { Private consumers } \\
\text { Private companies }\end{array}$ & $\begin{array}{l}\text { Most suitable for pri- } \\
\text { vate consumers and } \\
\text { companies, but could } \\
\text { also be applied to us- } \\
\text { ers of, for instance, } \\
\text { public goods }\end{array}$ & $\begin{array}{l}\text { Public authorities } \\
\text { Private consumers } \\
\text { Private companies }\end{array}$ & $\begin{array}{l}\text { Public authorities } \\
\text { Private consumers } \\
\text { Private companies }\end{array}$ \\
\hline $\begin{array}{l}\text { Who is likely to use } \\
\text { the nudge for push- } \\
\text { ing an environmental } \\
\text { agenda? }\end{array}$ & $\begin{array}{l}\text { Utility companies } \\
\text { Public authorities } \\
\text { NGOs } \\
\text { Private companies }\end{array}$ & $\begin{array}{l}\text { Utility companies } \\
\text { Private companies }\end{array}$ & $\begin{array}{l}\text { Utility companies } \\
\text { Public authorities } \\
\text { Private companies }\end{array}$ & $\begin{array}{l}\text { Utility companies } \\
\text { Public authorities } \\
\text { Charity organisations } \\
\text { NGOs }\end{array}$ \\
\hline $\begin{array}{l}\text { Gender-specific is- } \\
\text { sues }\end{array}$ & $\begin{array}{l}\text { Missing knowledge } \\
\text { on gender influence }\end{array}$ & $\begin{array}{l}\text { Missing knowledge } \\
\text { on gender influence }\end{array}$ & $\begin{array}{l}\text { Missing knowledge } \\
\text { on gender influence }\end{array}$ & $\begin{array}{l}\text { Missing knowledge } \\
\text { on gender influence }\end{array}$ \\
\hline Price of nudge & $\begin{array}{l}\text { Knowledge generally } \\
\text { not disclosed on the } \\
\text { cost of imposing the } \\
\text { nudge }\end{array}$ & $\begin{array}{l}\text { Knowledge generally } \\
\text { not disclosed on the } \\
\text { cost of imposing the } \\
\text { nudge }\end{array}$ & $\begin{array}{l}\text { Knowledge generally } \\
\text { not disclosed on the } \\
\text { cost of imposing the } \\
\text { nudge }\end{array}$ & $\begin{array}{l}\text { Knowledge generally } \\
\text { not disclosed on the } \\
\text { cost of imposing the } \\
\text { nudge }\end{array}$ \\
\hline
\end{tabular}


Although most reviewed cases and examples target private consumers and households with the exception of, for instance, cases 5 and 11, the use of nudges - e.g. for changing default office temperatures and introducing energy reports with peer reviews - may also work outside the private sphere.

Careful consideration of how to offer recycling options within public facilities could be one way of reducing the impact of waste. The reviewed literature provides examples of assessed goods and target groups, but the application does not have to be confined to these settings. 



\section{Mapping of literature and experiments}

Table 15, Table 16 and Table 17 contain short summaries of the cases and experiments identified in the reviewed literature. We have subdivided cases and experiments into themes according to whether the nudge relates to energy consumption, energy efficiency, waste and other resource uses. The cases and experiments reviewed cover a broad range of literature, including publicly available reports and scientific articles. We have identified a total of 30 different cases and experiments, covering approximately 16 different nudges with the vast majority being from the US. Where possible, the validity of the results are supported by references to control group size.

The effect of nudging spans from a negative impact of offering a recycling option, to reductions in energy consumption of up to $40 \%$ in peak hours and food waste reductions in the order of $135 \%$. The review thus confirms that effective nudging requires careful consideration of the motivations of the target group and design of the specific nudge.

Table 6: Overview of experiments identified in energy consumption

\begin{tabular}{|c|c|c|c|c|c|c|}
\hline Case & Theme & Type of nudge & $\begin{array}{l}\text { Environmental pol- } \\
\text { icy theme }\end{array}$ & $\begin{array}{l}\text { Rating of the success of } \\
\text { the experiment }\end{array}$ & $\begin{array}{l}\text { Scale of the ex- } \\
\text { periment }\end{array}$ & $\begin{array}{l}\text { Country / } \\
\text { countries }\end{array}$ \\
\hline 1 & $\begin{array}{l}\text { Peer compar- } \\
\text { ison feedback } \\
\text { in households }\end{array}$ & $\begin{array}{l}\text { Provision of in- } \\
\text { formation, and } \\
\text { use of social } \\
\text { norms }\end{array}$ & Energy consumption & $\begin{array}{l}\text { Electricity and gas usage } \\
\text { decreased by } 1.2 \% \text { on aver- } \\
\text { age. }\end{array}$ & $\begin{array}{l}84,000 \text { house- } \\
\text { holds }\end{array}$ & US \\
\hline 2 & Green lights & $\begin{array}{l}\text { Provision of in- } \\
\text { formation giv- } \\
\text { ing direct feed- } \\
\text { back on energy } \\
\text { prices }\end{array}$ & Energy consumption & $\begin{array}{l}\text { The electricity usage was } \\
\text { reduced by } 40 \% \text { in the } \\
\text { hours with the heaviest } \\
\text { load. }\end{array}$ & 120 households & US \\
\hline 3 & $\begin{array}{l}\text { Green button } \\
\text { energy usage }\end{array}$ & $\begin{array}{l}\text { Provision of in- } \\
\text { formation }\end{array}$ & $\begin{array}{l}\text { Energy consumption } \\
\text { through direct feed- } \\
\text { back information on } \\
\text { energy use }\end{array}$ & Unknown & $\begin{array}{l}55 \text { million Amer- } \\
\text { icans can access } \\
\text { their energy us- } \\
\text { age through the } \\
\text { green button }\end{array}$ & US \\
\hline 4 & $\begin{array}{l}\mathrm{CO}_{2} \text { - offset- } \\
\text { ting for air } \\
\text { transport }\end{array}$ & $\begin{array}{l}\text { Change in de- } \\
\text { fault }\end{array}$ & $\begin{array}{l}\text { Decrease in indirect } \\
\text { energy consumption } \\
\text { through offsets }\end{array}$ & $\begin{array}{l}\mathrm{CO}_{2} \text { offsets as default in- } \\
\text { creased share that chose to } \\
\text { offset by } 4 \% \text { pts. }\end{array}$ & $\begin{array}{l}240 \text { conference } \\
\text { participants }\end{array}$ & Sweden \\
\hline
\end{tabular}




\begin{tabular}{|c|c|c|c|c|c|c|}
\hline Case & Theme & Type of nudge & $\begin{array}{l}\text { Environmental pol- } \\
\text { icy theme }\end{array}$ & $\begin{array}{l}\text { Rating of the success of } \\
\text { the experiment }\end{array}$ & $\begin{array}{l}\text { Scale of the ex- } \\
\text { periment }\end{array}$ & $\begin{array}{l}\text { Country / } \\
\text { countries }\end{array}$ \\
\hline 5 & $\begin{array}{l}\text { Energy } \\
\text { nudges in } \\
\text { U.K. central } \\
\text { government } \\
\text { offices }\end{array}$ & $\begin{array}{l}\text { Provision of in- } \\
\text { formation, } \\
\text { changes in de- } \\
\text { fault, use of so- } \\
\text { cial norms }\end{array}$ & $\begin{array}{l}\text { Energy consumption } \\
\text { changing default } \\
\text { temperature, real- } \\
\text { time displays, online } \\
\text { reports of energy use }\end{array}$ & $\begin{array}{l}\text { Carbon emissions reduced } \\
\text { by } 10 \% \text { in one year. }\end{array}$ & $\begin{array}{l}300,000 \text { civil } \\
\text { servants in 3,000 } \\
\text { buildings }\end{array}$ & UK \\
\hline 6 & $\begin{array}{l}\text { Opower } \\
\text { Home Energy } \\
\text { Reporting } \\
\text { Program }\end{array}$ & $\begin{array}{l}\text { Provision of in- } \\
\text { formation, use } \\
\text { of social norms }\end{array}$ & Energy consumption & $\begin{array}{l}\text { Average energy savings in } \\
\text { the order of } 2-3 \%\end{array}$ & Unknown & US \\
\hline 7 & $\begin{array}{l}\text { Political ide- } \\
\text { ology and en- } \\
\text { ergy conser- } \\
\text { vation } \\
\text { nudges }\end{array}$ & $\begin{array}{l}\text { Provision of in- } \\
\text { formation and } \\
\text { use of social } \\
\text { norms }\end{array}$ & $\begin{array}{l}\text { Energy consumption } \\
\text { through feedback } \\
\text { reports using peer } \\
\text { comparisons }\end{array}$ & $\begin{array}{l}\text { Liberals reduced consump- } \\
\text { tion by } 3 \% \text { while Republican } \\
\text { households increased con- } \\
\text { sumption by up to } 1 \%\end{array}$ & $\begin{array}{l}85,000 \text { house- } \\
\text { holds } \\
\text { Control } \\
(\mathrm{N}=49,000) \\
\text { Treatment } \\
(\mathrm{N}=35,000)\end{array}$ & US \\
\hline 8 & $\begin{array}{l}\text { Peer compar- } \\
\text { ison feedback } \\
\text { in households }\end{array}$ & $\begin{array}{l}\text { Provision of in- } \\
\text { formation }\end{array}$ & $\begin{array}{l}\text { Energy consumption } \\
\text { through feedback } \\
\text { reports using peer } \\
\text { comparisons }\end{array}$ & $\begin{array}{l}\text { Energy consumption re- } \\
\text { duced by } 1.5-7 \%\end{array}$ & $\begin{array}{l}\text { Total of 159,000 } \\
\text { households }\end{array}$ & US \\
\hline 9 & $\begin{array}{l}\text { Frequent en- } \\
\text { ergy feed- } \\
\text { back and } \\
\text { peer compar- } \\
\text { ison }\end{array}$ & $\begin{array}{l}\text { Provision of in- } \\
\text { formation, and } \\
\text { use of social } \\
\text { norms }\end{array}$ & Energy consumption & $\begin{array}{l}\text { The average usage of en- } \\
\text { ergy decreased by } 2.5 \% \text { and } \\
\text { the usage in "rush hour" de- } \\
\text { creased by } 8.8 \%\end{array}$ & $\begin{array}{l}5,500 \text { house- } \\
\text { holds }\end{array}$ & Ireland \\
\hline 10 & $\begin{array}{l}\text { Real-time } \\
\text { feedback on } \\
\text { price and } \\
\text { consumption }\end{array}$ & $\begin{array}{l}\text { Provision of in- } \\
\text { formation }\end{array}$ & Energy consumption & $\begin{array}{l}\text { Price information alone re- } \\
\text { duced consumption be- } \\
\text { tween } 0-13 \% \text {. Both price } \\
\text { and real-time information } \\
\text { price and quantity con- } \\
\text { sumed reduced by } \\
8-22 \%\end{array}$ & $\begin{array}{l}437 \text { households } \\
\text { Control }(\mathrm{N}=207) \\
\text { Treatment } \\
(\mathrm{N}=237)\end{array}$ & US \\
\hline 11 & $\begin{array}{l}\text { OECD ther- } \\
\text { mostat set- } \\
\text { tings }\end{array}$ & $\begin{array}{l}\text { Change in de- } \\
\text { fault option, re- } \\
\text { ducing temper- } \\
\text { ature with 1, } \\
\text { and } 3 \text { degrees }\end{array}$ & Energy consumption & $\begin{array}{l}\text { A } 1 \text { degree reduction in tem- } \\
\text { perature reduces the energy } \\
\text { use, while a } 3 \text { degree reduc- } \\
\text { tion leads to increase in en- } \\
\text { ergy use through manual } \\
\text { regulation }\end{array}$ & $\begin{array}{l}93 \text { offices in } \\
\text { OECD's Mar- } \\
\text { shall building }\end{array}$ & France \\
\hline 12 & Smart grid & $\begin{array}{l}\text { Changes in de- } \\
\text { fault }\end{array}$ & Energy consumption & $\begin{array}{l}\text { When Smart Grid was the } \\
\text { default, } 79 \% \text { accepted hav- } \\
\text { ing the technology installed. } \\
\text { When it was not the default, } \\
60 \% \text { accepted. }\end{array}$ & 151 households & Denmark \\
\hline 13 & $\begin{array}{l}\text { In-home en- } \\
\text { ergy displays }\end{array}$ & $\begin{array}{l}\text { Provision of in- } \\
\text { formation }\end{array}$ & $\begin{array}{l}\text { Energy consumption } \\
\text { through real-time } \\
\text { information }\end{array}$ & $\begin{array}{l}\text { The average household re- } \\
\text { duced consumption by } 11 \% \\
\text { depending on time of the } \\
\text { day }\end{array}$ & $\begin{array}{l}65 \text { households } \\
\text { for a total of } 90 \\
\text { days }\end{array}$ & US \\
\hline
\end{tabular}


A closer look at the experiments and cases from the literature review (Table 15) shows that different types of nudges in the form of information provision or in a combination with social norms can be a powerful means of reducing energy consumption. Such nudges can be realtime information on energy consumption on in-home displays that provide updated information on current energy prices and/or current consumption to households. Studies have found that real-time information can reduce energy consumption by up to $40 \%$ during peak load hours (cases 2, 3, 10, 13).

Similarly, a range of studies in the US, the UK and Ireland have documented that combining information provision with social nudges (social feedback combined with frequent information on current energy consumption patterns) can reduce energy consumption by up to $7 \%$ (cases 1 and 5 to 9 ).

Social nudges can be applied not only to the energy sector, but also to other utilities such as water and waste. In water usage, the program WaterSmart is estimated to have reduced water use by $5 \%$ by a combination of feedback reports and peer comparisons (case 27, Table 17). Feedback reports with peer comparisons are thus not restricted to one utility service, but can be applied broadly across a mix of different agents, including households, industry and public sectors, for instance allowing industrial companies to compare their energy usage per employee to other similar businesses.

When we reviewed the examined literature related to energy efficiency nudges, see Table 16, cases $14-16,19$ and 20, a recurrent theme was the use of energy labelling to inform consumers of the energy efficiency of a varied set of durable products ranging from household appliances to the energy performance of houses. Common to the examined cases is the purchase of goods where the decision to buy will affect energy use over a longer period, and where the infrequent purchase choice increases the uncertainty of the impact of choosing one option over another. Energy labelling can help bridge that information gap, by acting as a foundation to which the efficiency of goods can be compared.

The literature has shown that the likelihood of choosing an energy-efficient household appliance increases if the consumer receives information on the relative performance of the appliance versus another product. This can, for instance, be achieved by using labelling such as the Energy star or the European energy label, rather than merely providing information on the energy consumption of a product (see for instance case 20). 
Table 7: Overview of experiments identified in energy efficiency

\begin{tabular}{|c|c|c|c|c|c|c|}
\hline Case & & $\begin{array}{l}\text { Type of } \\
\text { nudge }\end{array}$ & $\begin{array}{l}\text { Environmental } \\
\text { policy theme }\end{array}$ & $\begin{array}{l}\text { Rating of the success of } \\
\text { the experiment }\end{array}$ & $\begin{array}{l}\text { Scale of the ex- } \\
\text { periment }\end{array}$ & $\begin{array}{l}\text { Country I } \\
\text { countries }\end{array}$ \\
\hline 14 & $\begin{array}{l}\text { Improve en- } \\
\text { ergy labelling } \\
\text { of household } \\
\text { appliances }\end{array}$ & $\begin{array}{l}\text { Provision of } \\
\text { information } \\
\text { through la- } \\
\text { belling }\end{array}$ & Energy efficiency & $\begin{array}{l}\text { Products sold in the test } \\
\text { period with improved la- } \\
\text { belling was } 5 \% \text { more effi- } \\
\text { cient than products sold } \\
\text { in the control period }\end{array}$ & Not mentioned & UK \\
\hline 15 & $\begin{array}{l}\text { John Lewis en- } \\
\text { ergy labelling } \\
\text { trial }\end{array}$ & $\begin{array}{l}\text { Provision of } \\
\text { information }\end{array}$ & $\begin{array}{l}\text { Promotion of en- } \\
\text { ergy efficiency } \\
\text { through labelling } \\
\text { of household ap- } \\
\text { pliances }\end{array}$ & $\begin{array}{l}\text { Energy labelling reduced } \\
\text { the average annual con- } \\
\text { sumption of washer dry- } \\
\text { ers by } 6.64 \mathrm{kWh}\end{array}$ & $\begin{array}{l}38 \text { John Lewis Part- } \\
\text { ners participated } \\
\text { from September } \\
2013 \text { to June } 2014 \text {. } \\
\text { Control }(\mathrm{N}=19) \\
\text { Treatment }(\mathrm{N}=19)\end{array}$ & UK \\
\hline 16 & $\begin{array}{l}\text { Energy Per- } \\
\text { forming Certif- } \\
\text { icates of Hous- } \\
\text { ing }\end{array}$ & $\begin{array}{l}\text { Provision of } \\
\text { information } \\
\text { through la- } \\
\text { belling }\end{array}$ & $\begin{array}{l}\text { Energy consump- } \\
\text { tion }\end{array}$ & $\begin{array}{l}\text { Unknown, but } 17 \% \text { of } \\
\text { people report acting on } \\
\text { recommendations in the } \\
\text { EPC. }\end{array}$ & Unknown & UK \\
\hline 17 & $\begin{array}{l}\text { Green electric- } \\
\text { ity defaults } \\
\text { Schönau }\end{array}$ & $\begin{array}{l}\text { Change in de- } \\
\text { fault option }\end{array}$ & Energy efficiency & $\begin{array}{l}\text { After } 8 \text { years, nearly } \\
\text { every customer remained } \\
\text { within the green default }\end{array}$ & 2,500 households & Germany \\
\hline 18 & $\begin{array}{l}\text { Green electric- } \\
\text { ity defaults, } \\
\text { Energiedienst } \\
\text { GmbH }\end{array}$ & $\begin{array}{l}\text { Provision of } \\
\text { information } \\
\text { and change in } \\
\text { default op- } \\
\text { tion }\end{array}$ & Energy efficiency & $\begin{array}{l}\text { About } 94 \% \text { of the cus- } \\
\text { tomers remained with } \\
\text { the green default }\end{array}$ & $\begin{array}{l}150,000 \text { private } \\
\text { and business cus- } \\
\text { tomers }\end{array}$ & Germany \\
\hline 19 & $\begin{array}{l}\text { Changing the } \\
\text { energy label }\end{array}$ & $\begin{array}{l}\text { Provision of } \\
\text { information }\end{array}$ & $\begin{array}{l}\text { Energy efficiency } \\
\text { though labelling }\end{array}$ & $\begin{array}{l}\text { Change in the scale of en- } \\
\text { ergy label from A-G to A- } \\
\text { A+++ reduced the likeli- } \\
\text { hood of choosing an en- } \\
\text { ergy efficient TV by } 4.4 \\
\text { times }\end{array}$ & Unknown & Denmark \\
\hline 20 & $\begin{array}{l}\text { Labelling of } \\
\text { household ap- } \\
\text { pliances }\end{array}$ & $\begin{array}{l}\text { Provision of } \\
\text { information }\end{array}$ & $\begin{array}{l}\text { Energy efficiency } \\
\text { though labelling }\end{array}$ & $\begin{array}{l}\text { Labelling increased the } \\
\text { likelihood of choosing en- } \\
\text { ergy efficiency products, } \\
\text { more than only providing } \\
\text { information on energy } \\
\text { usage }\end{array}$ & 1,217 respondents & US \\
\hline
\end{tabular}

The impact of using energy labelling is frequently uncertain, but some studies (see case 14) suggest that energy labelling may increase the choice of energy-efficient products by $5 \%$. When examining the impact of energy labels on house prices, a study in the Netherlands found that houses with a green label sell at a $3.6 \%$ premium compared 
with otherwise comparable homes. ${ }^{5} \mathrm{~A}$ similar Danish study found a price premium of approximately DKK 180,000 for houses built to high-energy standards. ${ }^{6}$

Other examples of energy efficiency promoting nudges include the use of green standards. A German study (cases 17 and 18) found that almost all consumers remain with the green default, when the default is changed from conventional energy to green energy. As such, changing the default can be a useful tool to promote pro-environmental behaviour and change the inconsistency between people's stated positive attitude towards green sources of energy and actual behaviour in refraining from choosing greener options under "the grey default."

The literature reviewed did not exclusively evolve around energy consumption and efficiency, aspects of waste generation, sustainable consumption and waste usage were also included, see Table 17.

Table 8: Overview of experiments identified related to waste management and other resources

\begin{tabular}{|c|c|c|c|c|c|c|}
\hline Case & & Type of nudge & $\begin{array}{l}\text { Environmental } \\
\text { policy theme }\end{array}$ & $\begin{array}{l}\text { Rating of the success of } \\
\text { the experiment }\end{array}$ & $\begin{array}{l}\text { Scale of the experi- } \\
\text { ment }\end{array}$ & $\begin{array}{l}\text { Country / } \\
\text { countries }\end{array}$ \\
\hline 21 & $\begin{array}{l}\text { "Love Food, } \\
\text { Hate Waste" }\end{array}$ & $\begin{array}{l}\text { Provision of infor- } \\
\text { mation through } \\
\text { social media }\end{array}$ & $\begin{array}{l}\text { Reduction of } \\
\text { food waste }\end{array}$ & $\begin{array}{l}\text { Unknown effect. Estimated } \\
\text { that } 1.8 \text { million households } \\
\text { are cutting back on food } \\
\text { waste }\end{array}$ & National campaign & UK \\
\hline 22 & $\begin{array}{l}\text { "Use More, } \\
\text { Waste Less" }\end{array}$ & $\begin{array}{l}\text { Provision of infor- } \\
\text { mation through } \\
\text { social media }\end{array}$ & $\begin{array}{l}\text { Reduction of } \\
\text { food waste }\end{array}$ & $\begin{array}{l}\text { Unknown effect, but } 3 \% \\
\text { state that they will throw } \\
\text { away less food, } 12 \% \text { state } \\
\text { they have increased their } \\
\text { food awareness. }\end{array}$ & National campaign & Denmark \\
\hline 23 & $\begin{array}{l}\text { Recycling gone } \\
\text { bad }\end{array}$ & $\begin{array}{l}\text { Changes in the } \\
\text { physical environ- } \\
\text { ment }\end{array}$ & Paper waste & $\begin{array}{l}\text { The option to recycle in- } \\
\text { creased waste generation } \\
\text { by about } 20 \% \text {. }\end{array}$ & $\begin{array}{l}1 \text { restroom at a Uni- } \\
\text { versity campus }\end{array}$ & US \\
\hline 24 & "Ecochallenge" & $\begin{array}{l}\text { Provision of infor- } \\
\text { mation though so- } \\
\text { cial media }\end{array}$ & $\begin{array}{l}\text { Reduction in } \\
\mathrm{CO}_{2} \text { emission } \\
\text { from everyday } \\
\text { consumption } \\
\text { through "chal- } \\
\text { lenges" }\end{array}$ & $\begin{array}{l}\text { Unknown. } 8000 \text { approx. } \\
\text { downloads from February- } \\
\text { April } 2011\end{array}$ & National campaign & US \\
\hline
\end{tabular}

\footnotetext{
5 The Behavioural insight team (2011). Behaviour Change and Energy Use. London. London Cabinet Office. ${ }^{6}$ The Danish Energy Agency (2015). Is there a price premium for good energy standards of single homes? Copenhagen Economics.
} 


\begin{tabular}{|c|c|c|c|c|c|c|}
\hline Case & & Type of nudge & $\begin{array}{l}\text { Environmental } \\
\text { policy theme }\end{array}$ & $\begin{array}{l}\text { Rating of the success of } \\
\text { the experiment }\end{array}$ & $\begin{array}{l}\text { Scale of the experi- } \\
\text { ment }\end{array}$ & $\begin{array}{l}\text { Country I } \\
\text { countries }\end{array}$ \\
\hline 26 & Waste sorting & $\begin{array}{l}\text { Change in physical } \\
\text { environment and } \\
\text { provision of infor- } \\
\text { mation }\end{array}$ & $\begin{array}{l}\text { Promotion of } \\
\text { separation of } \\
\text { food waste us- } \\
\text { ing information } \\
\text { campaign and } \\
\text { new equipment } \\
\text { to for source- } \\
\text { segregation of } \\
\text { waste }\end{array}$ & $\begin{array}{l}\text { Information campaign had } \\
\text { no significant impact. } \\
\text { Source segregation in- } \\
\text { creased food waste sorting } \\
\text { by } 44-49 \%\end{array}$ & 320 households & Sweden \\
\hline 27 & WaterSmart & $\begin{array}{l}\text { Provision of infor- } \\
\text { mation and use of } \\
\text { social norms }\end{array}$ & $\begin{array}{l}\text { Water usage re- } \\
\text { duction through } \\
\text { feedback re- } \\
\text { ports and peer } \\
\text { comparisons }\end{array}$ & Estimated reduction of $5 \%$. & $\begin{array}{l}\text { Residential water us- } \\
\text { ers across the US }\end{array}$ & US \\
\hline 28 & $\begin{array}{l}\text { Changing the } \\
\text { plate size to re- } \\
\text { duce waste }\end{array}$ & $\begin{array}{l}\text { Change in physical } \\
\text { environment }\end{array}$ & $\begin{array}{l}\text { Reduction of } \\
\text { food waste }\end{array}$ & $\begin{array}{l}135.2 \% \text { more food was } \\
\text { wasted in diners with larger } \\
\text { plates }\end{array}$ & $\begin{array}{l}43 \text { diners ( } 51 \% \mathrm{fe}- \\
\text { males) }\end{array}$ & US \\
\hline 29 & $\begin{array}{l}\text { Weight vs. fee } \\
\text { based waste } \\
\text { collection-Ul- } \\
\text { stein Norway }\end{array}$ & $\begin{array}{l}\text { Changes in physi- } \\
\text { cal environment } \\
\text { and provision of } \\
\text { information }\end{array}$ & $\begin{array}{l}\text { Fee-based } \\
\text { waste sorting } \\
\text { using communi- } \\
\text { cation strategy } \\
\text { focusing on so- } \\
\text { cial norms }\end{array}$ & $\begin{array}{l}\text { Increase in both quantity } \\
\text { and quality of sorting }\end{array}$ & $\begin{array}{l}\text { Households in UI- } \\
\text { stein Municipality }\end{array}$ & Norway \\
\hline 30 & $\begin{array}{l}\text { Meat-free de- } \\
\text { fault menus }\end{array}$ & $\begin{array}{l}\text { Change in default } \\
\text { option }\end{array}$ & $\begin{array}{l}\text { Promotion of } \\
\text { more sustaina- } \\
\text { ble food choices } \\
\text { by providing a } \\
\text { meat-free } \\
\text { menu as the de- } \\
\text { fault option }\end{array}$ & $\begin{array}{l}\text { When the meat-free option } \\
\text { was the default, this was } \\
\text { chosen } 92.5 \% \text { of the times, } \\
\text { while the control group } \\
\text { chose the meat-free option } \\
47.5 \% \text { of the time. }\end{array}$ & $\begin{array}{l}320 \text { undergraduate } \\
\text { students at the cam- } \\
\text { pus of large univer- } \\
\text { sity in Midwestern } \\
\text { U.S. over a two- } \\
\text { week period }\end{array}$ & US \\
\hline
\end{tabular}

Of the students that were presented with the default meat-free option (including information on the consequences of going meat-free) $92.5 \%$ chose this menu, while only $47.5 \%$ of the students in the control groups chose the meat-free option.

Two main themes stand out from Table 17. The first is that a simple means such as reducing the size of the plate can reduce food consumption and food waste. A Norwegian and US study found that reducing the plate size might reduce food waste by between approximately $20 \%$ and an immense $135 \%$, depending on the setting, see cases 25 and 28.

First, changes in the physical environment of food choices thus offer an enormous potential for reducing resource use stemming from food production and food waste. 
Nudging through the provision of information shows less certain results, but social media campaigns in both the UK and Denmark aimed at reducing food waste have received considerable attention, cases 21 and 22.

Second, studies of waste collection and recycling show that waste sorting may bring about unexpected effects depending on the provision of information and the physical design of the sorting system. A Swedish study found no significant effect of an information campaign advocating food waste sorting, while changing the physical setup of the sorting system increased food waste sorting by $44-49 \%$ (case 26 ).

In a similar vein, a Norwegian study of household sorting behaviour found that coupling an information campaign focused on the financial incentive of sorting waste with a weight-based payment schedule in some instances led to "strategic behaviour." Some households polluted their plastic and paper waste by adding different waste types and left waste in neighbouring bins or by illegal waste dumping to reduce waste payment.

Redirecting the focus of the information campaign to social norms and social behaviour in combination with a fee-based payment schedule, where the payment was made according to number and size of bins led to improved sorting behaviour and eliminated almost all problems of strategic behaviour, (case 29) 



\section{Documentation of the pilot experiment}

\subsection{Introduction}

A frequently asked question by policy makers is how we can encourage people to make more environmentally friendly decisions. Why do people refrain from carbon compensating their flights or sort their waste? In this chapter, we focus on the role of nudges and how nudges can encourage people to make more environmentally friendly decisions. To better illustrate how nudges work, in particular when compared to each other, we have conducted a small tailor-made pilot field experiment on donation behaviour.

The objective of this chapter is to illustrate how the relative performance of different nudges can be tested by applying a field experimental approach, where we also carefully consider other factors that might influence the evaluation of different nudges. The key differences between a traditional lab experiment and real life are the subject pool and the awareness of being part of an experiment (see e.g., Harrison and List, 2004, for discussion). Thus, the key features of a field experiment are that it takes place in a naturally occurring situation and that subjects are not aware that they are taking part in an experiment. The case study for our pilot experiment involves analysing the effect of different nudges on the decision to donate the deposit when recycling beverage containers in a supermarket. This is a clean setup with a binary decision: either to donate to an environmental project or to keep the money yourself. By conducting the experiment in a supermarket, we can change the choice architecture in a controlled way, thereby avoiding confounding effects. Moreover, the situation is similar to other environmental decisions such as choosing renewable energy, travelling by bus or recycling, which are all binary decisions.

The pilot study illustrates how to test the relative effect of subtle interventions on donation behaviour. These interventions use nudges that neither change economic incentives nor forbid any type of behaviour. In particular, we compare three main categories of interventions, each having the following characteristics: (i) provision of information about the consequences of a donation, (ii) a change in the physical environment, and (iii) provision of information about social norms. Using a tailor-made field experiment, we find that each intervention has a positive but statistically insignificant 
effect on donations. We discuss the potential use of these broader classes of nudge interventions for different environmental goods, and the need for large-scale field experiments to establish more robust results on the efficiency of different nudges.

\subsection{Design of the pilot experiment}

\subsubsection{Literature review and focus groups}

As in all experimental work, a certain amount of homework is required before an experiment can be launched. As a first stage, we conducted a literature review of previous nudge studies and focus group studies with the participation of both academics with experience from field experiments and nudges that of non-academics. As mentioned above, we broadly categorise nudges into four groups: (i) provision of information, (ii) changes to physical environment, (iii) changes to the default policy and, (iv) provision of information about social norms (House of Lords, 2011).

Changes in provision of information can be made to provide information in a more direct and accessible way by stating the consequences of an action, (e.g., lifetime energy cost of durable goods (Kallbekken et al., 2013), feedback on energy use (Allcott and Rogers, 2014) and moral information (e.g., Fellner et al., 2013; Pruckner and Sausgruber, 2013)). Classical examples related to changes in the physical environment refer to location of healthy and unhealthy food such as on the menu or in the canteen (e.g., Goldberg and Gunasti, 2007) and size for food plates (Kallbekken and Sælen, 2013). The default option has shown to be powerful in many contexts (e.g., organ donations (Johnson and Goldstein 2003), pension saving (Madrian and Shea, 2001), default on printer (Egebark and Ekström, 2016)). This is elegantly summarised by DellaVigna (2009, p.322): "Overall, the finding of large default effects is one of the most robust results in the applied economics literature for the last ten years." Two types of social norms have typically been used: (i) descriptive and (ii) injunctive, the latter referring to what people ought to do (e.g., Cialdini, 2003). Both of these norms have mainly been applied to energy and water consumption with reduction of usage as a result (e.g., Allcott, 2011; Costa and Kahn, 2013).

The focus groups resulted in several insightful comments and conclusions. The nudges related to provision of information and changes to the physical environment are context specific, which is also indicated in the brief literature review above. Thus, some general principles can be extracted and generalised, but care should be taken when developing these two nudges. The default option has a strong effect on behaviour, but it cannot be used in the cases when there is no natural default. For example, it is easy to implement carbon compensation for flights by using an opt-out option, where people 
have to opt out if they do not want to compensate, but this is harder to implement for garbage collection. In general, the default option has been shown to have a strong effect on behaviour and should be used whenever possible.7 Social norm is a potentially very promising nudge, but little is known about who influences us most. Are people more likely to adopt other people's energy consumption if this group of people is represented as the neighbours or colleagues at work? In addition, this nudge is the easiest to generalise and to apply to different environmental goods.

\subsubsection{Experimental design and procedures and predictions}

The experiment was conducted at a CO-OP supermarket near Gothenburg, Sweden. The supermarket has reverse vending machines for beverage containers with deposits. Since 1984, Sweden has a deposit return scheme for aluminium cans, glass and PET bottles of different sizes. ${ }^{8}$ The reverse vending machines at the CO-OP supermarket offer two options after the cans and bottles have been deposited: (i) cash payment, which is obtained from the cashier at the supermarket, or (ii) donation to a charity. The donations benefit the organisation "Vi-skogen" ("Our forest"), which is a Swedish development cooperation organisation aiming at reducing poverty and improving the environment through tree planting (see Vi-skogen, 2016). ${ }^{9}$

The reverse vending machines in our supermarket were located close to the entrance/exit. Figure 51 below shows a photo of the machine used for the experiment. For the experiment, we added an information sign just below the display, which shows the deposit amount and has the opening for bottles and cans, (there was not enough space to add the information sign in between). For items deposited through the machine, the shopper will be given the binary decision of redeeming the amount or donating it to charity.

\footnotetext{
7 Löfgren et al. (2012) discuss that the effect of nudges attenuates by experiences. For a discussion on people's views on using nudges see e.g., Hagman et al. (2015).

${ }^{8}$ The abbreviation PET refers to bottles made of the recyclable material polyethylene terephthalate.

9 Since the organisation was established in 1983 , it has planted over 100 million trees mostly in sub-Saharan Africa.
} 
Figure 1: Recycling machine with information sign

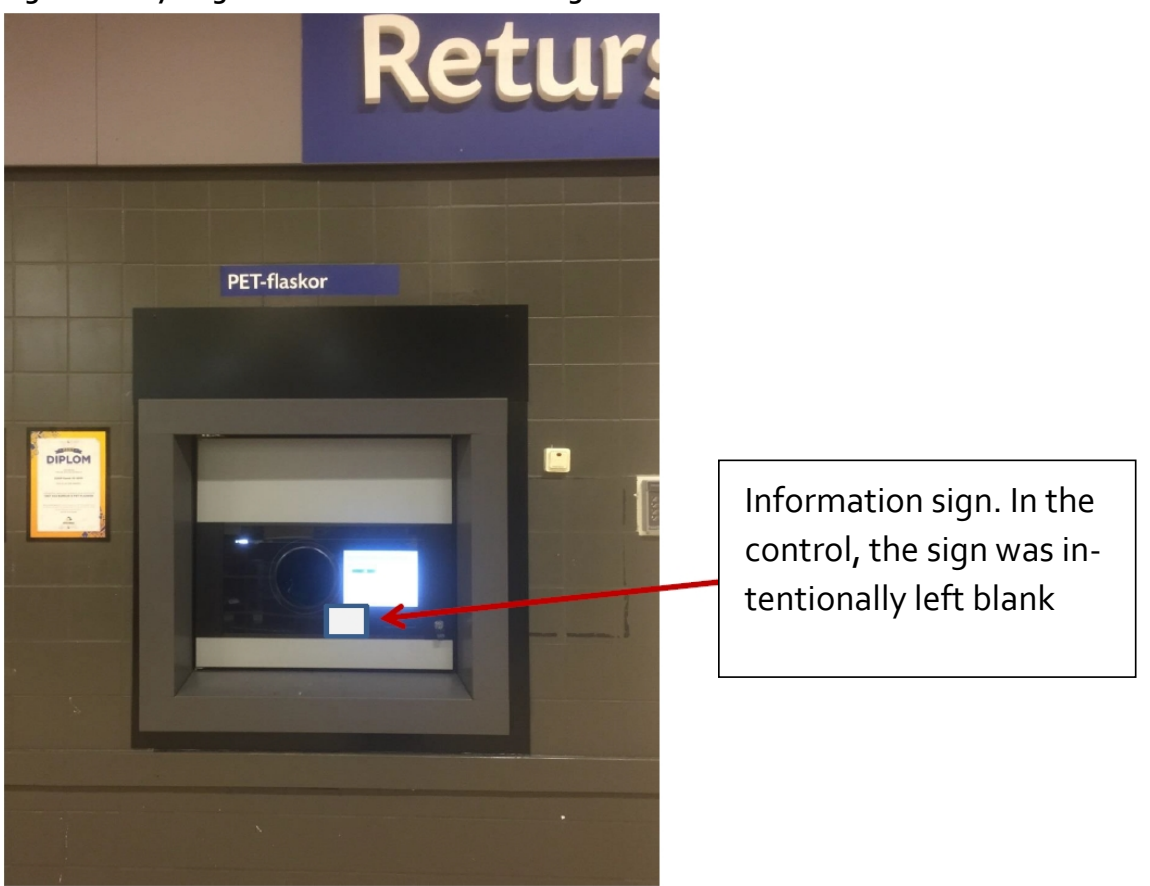

Our experimental design contained a control and three different "treatments" using three different nudges. A summary of the experimental design is given in Table 18. In the control experiment, a blank sign is attached to the machine. The reverse vending machine with the information sign is depicted in Figure 1 above. We used the information sign to relay the messages relating to each of the three different treatments. To avoid influencing the decision environment - to the extent possible - between the control and the treatment, we kept the information sign but left it blank in the control experiment. $^{10}$

In the treatment where information was provided, the following text message appeared: "Donate your deposit to the charity 'Vi-skogen' that helps lift people out of poverty by planting trees."

The idea is to inform about the direct effect of donation and the welfare implications. The tree planting has a direct impact on the welfare of the families living in the

\footnotetext{
${ }^{10}$ We firmly believe that having an empty information sign or no information sign at all would not affect the donation pattern. However, to rule out any confounded effect of changing to things, i.e., having an information sign per se and information text, we decided to have an empty information sign in the control.
} 
area where the trees are planted but the project also benefits the globe as a whole from a climate change perspective. The second treatment refers to a change in the physical environment. Here, we included an arrow pointing to the donation button. The aim was to reduce the effort needed to make a choice. In the third treatment relating to social norms, the shoppers were given a reference amount reflecting the proportion of people who donated in the past. In 2015, 73,505 shoppers recycled their bottles and cans in the supermarket and $6 \%$ of them also made donations. ${ }^{11}{ }^{12}$ The specific text used on the information sign was "On average, $6 \%$ of the customers in this supermarket donate their deposit from recycling to the charity Vi-skogen."

Table 9: Experimental design

\begin{tabular}{|c|c|}
\hline Type of nudge & Information sign \\
\hline Control & Intentionally left blank \\
\hline T1: Provision of information & $\begin{array}{l}\text { "Donate your deposit to the charity Vi-skogen that helps lift people out } \\
\text { of poverty by planting trees." }\end{array}$ \\
\hline T2: Changes in the physical environment & An arrow pointing at the donation button. \\
\hline T3: Social norms & $\begin{array}{l}\text { "On average, } 6 \% \text { of the customers in this supermarket donate their de- } \\
\text { posit from recycling to the charity Vi-skogen." }\end{array}$ \\
\hline
\end{tabular}

It is important to understand the behavioural mechanism behind a nudge in order to be able to forecast behaviour resulting from its implementation. Standard economic models assume that utility is only affected by extrinsic motivation, i.e., money, without any other concerns. ${ }^{13}$ Many models have been developed to consider other attributes that affect utility besides extrinsic motivation. For example, Bénabou and Tirole (2006) include intrinsic motivation, e.g., altruism, and reputation. In the case of environmental goods, the model captures the trade-off between a more selfish action and a more prosocial action, where the observed decision depends on the relative weight attached to these three main attributes. For example, this model framework then predicts, ceteris paribus, that people will not litter just because it is convenient for them (altruism effect) and will litter even less in front of other people (reputation effect).

\footnotetext{
${ }^{11}$ Personal communication with Tomra, March, 2016.

${ }^{12}$ Our experiment took place during the month of April, and based on 2015 recycling data, this corresponded to an average month in terms of quantity recycled.

${ }^{13}$ For an excellent introduction to behavioural and experimental economics, see e.g., Cartwright (2014).
} 
We consider that changes in behaviour in our experiment primarily arise from two motivational sources: 1 ) intrinsic motivation, i.e. the stable utility derived from performing prosocial acts, and 2) reputation, i.e. the utility reward from others viewing the individual as being prosocial (see e.g. Bénabou and Tirole, 2006). In case of a purely extrinsically motivated individual, the prediction is that none of the nudges will affect the individual's behaviour. However, most people are affected at least to some extent by intrinsic motivation or reputation, or both.

Below, we discuss our predictions as changes from the control scenario, i.e., the information sign without any text. In the first treatment, where we provide additional information, we expect an additional effect compared with the control. We reason that the reminder about the poverty of the recipients will make the act more salient, and hence increase its value. In the second treatment, which refers to a change in the physical environment by including an arrow pointing at the donation button, a similar line of reasoning applies; we expect a weakly positive enhancement due to salience. Finally, in the treatment for social norms the behavioural effect depends on the honour derived from being prosocial and the stigma from abstaining from prosocial behaviour. In general, the strongest effect on prosocial behaviour is expected when few decision makers are motivated by honour and when many are motivated by stigma from abstention. Given the experience that few people actually donate, we expect a net positive effect compared with the control. Overall, we expect net positive effects in all treatments, compared with the control. It is, however, difficult to predict which of the treatments that will perform best.

We conducted the experiment during four days, on Wednesdays and Thursdays for two consecutive weeks. We chose Wednesday and Thursday since we were informed that these two days were most similar in terms of characteristics of the shoppers. We began the experiment at 12 noon and finished at 8pm since we expected most visits to take place between these hours. This would likely yield the most representative sample. We can assume that certain groups of people self-select themselves to shopping and hence recycling at different times of the day. For example, we could expect that retired people are more likely to shop during the day while employed people shop during the evening. To cater for this fact, we changed treatment every 30 minutes cyclically. Moreover, each day we began with a different treatment to ensure a completely balanced data collection regarding the time of the day.

The data was collected by having a researcher stand nearby the recycling machine, but not so close that it would affect donation behaviour. The researcher noted the gender and approximate age in 10-year intervals, the number of cans and bottles deposited, and whether or not the money redeemed was donated to the charity. In addition, 
the researcher noted whether the person was alone or in a group and if another person(s) were observing at the time when the decision to donate had to be made.

\subsection{Results ${ }^{14}$}

Our treatments were changed cyclically every 30 minutes with the purpose of successfully randomising people to different treatments. We began to investigate the randomisation, and below in Table 19 we show the characteristics of the subjects by treatment. In the column to the right, we test if there are any differences between the control and treatments using a joint chi $^{2}$-est. As can be seen from the table, there are no systematic differences, showing that our randomisation by cyclically changing treatments every 30 minutes have has well.

Table 10: Descriptive statistics

\begin{tabular}{|c|c|c|c|c|c|}
\hline Variable & $\begin{array}{r}\text { Control } \\
(n=88)\end{array}$ & $\begin{array}{r}\text { Provision of in- } \\
\text { formation } \\
(n=67)\end{array}$ & $\begin{array}{r}\text { Changes in the } \\
\text { physical environ- } \\
\text { ment } \\
(n=84)\end{array}$ & $\begin{array}{r}\text { Social norms } \\
(\mathrm{n}=\mathbf{8 1})\end{array}$ & $\begin{array}{r}\text { Ho: } \\
\text { No difference } \\
\text { (p-value) }\end{array}$ \\
\hline Female & $28.4 \%$ & $38.8 \%$ & $35.7 \%$ & $38.3 \%$ & 0.47 \\
\hline Age & & & & & 0.09 \\
\hline Below 21 & $0.0 \%$ & $3.0 \%$ & $0.0 \%$ & $0.0 \%$ & \\
\hline 21-30 & $9.1 \%$ & $14.9 \%$ & $17.9 \%$ & $23.5 \%$ & \\
\hline $31-40$ & $22.7 \%$ & $9.0 \%$ & $21.4 \%$ & $11.1 \%$ & \\
\hline $41-50$ & $25.0 \%$ & $22.4 \%$ & $21.4 \%$ & $17.3 \%$ & \\
\hline $51-60$ & $20.5 \%$ & $22.4 \%$ & $20.2 \%$ & $29.6 \%$ & \\
\hline 61-70 & $13.6 \%$ & $16.4 \%$ & $14.3 \%$ & $11.1 \%$ & \\
\hline Above 70 & $9.1 \%$ & $11.9 \%$ & $4.8 \%$ & $7.4 \%$ & \\
\hline
\end{tabular}

The results for each treatment were summarised and an overview of the results is provided in Table 20. It appears from the table that a larger proportion of people donated in the treatment experiments compared with the control experiment, where $2.3 \%$ of people made a donation. The greatest proportion of donating people was observed in the social norms and provision of information treatments where $4.9 \%$ and $4.5 \%$ made a donation, respectively. However, the differences between control and treatments are not statistically significant - as can be seen in the column to the right where we report from a joint test of significance.

\footnotetext{
${ }^{14}$ For a detailed discussion of the results, see Knutsson et al. (2016).
} 
Table 11: Descriptive statistics of proportion who donated by treatment

\begin{tabular}{l|r|r|r|r}
\hline Control & $\begin{array}{r}\text { Provision of infor- } \\
\text { mation }\end{array}$ & $\begin{array}{r}\text { Changes in the } \\
\text { physical environ- } \\
\text { ment }\end{array}$ & $\begin{array}{r}\text { Social norms } \\
\text { Ove: No difference } \\
\text { ( } \mathbf{p} \text {-value) }\end{array}$ \\
\hline
\end{tabular}

In Table 21 we show the regression results:

- Model 1 tests whether any of the three treatments affects the probability of people making a donation. The results are in line with the summary in Table 20, indicating that each of the three different nudges tested in our field experiment had a positive but insignificant effect on people's propensity to donate and that provision of information and social norms perform best.

- In Model 2, we included a dummy variable for gender. The result indicates that females are (insignificantly) more prone to donating their deposit to charity.

- Model 3 investigates whether the gender effect is different across the treatments, and it seems that it is more pronounced in the information and physical environment treatments than the social norms treatment where the difference between males and females are smaller.

Table 12: Probit regression results

\begin{tabular}{lcrr} 
& $\begin{array}{r}\text { Model 1 } \\
\text { Coeff./Std.err) }\end{array}$ & $\begin{array}{r}\text { Model 2 } \\
\text { Coeff. /Std.err) }\end{array}$ & $\begin{array}{r}\text { Model 3 } \\
\text { Coeff. /Std.err) }\end{array}$ \\
$\begin{array}{l}\text { Provision of information } \\
\text { Changes in the physical environment }\end{array}$ & $0.26(0.41)$ & $0.21(0.42)$ & $0.16(0.59)$ \\
Social norms & $0.07(0.41)$ & $0.04(0.42)$ & $-0.04(0.59)$ \\
Female & $0.22(0.40)$ & $0.21(0.40)$ & $0.29(0.52)$ \\
Provision of information * Female & & $0.34(0.28)$ & $0.34(0.63)$ \\
Changes in the physical environment * Female & & & $0.10(0.85)$ \\
Social norms * Female & & & $0.14(0.84)$ \\
Number of observations & 320 & 320 & $-0.18(0.80)$ \\
\hline
\end{tabular}

Note: Note. In the regressions, we control for time of the day and if observed at the time of making the decision. Standard errors are reported within parentheses. 
To summarise, our results indicate that the nudges we tested in our pilot field experiment all have a positive effect on people's willingness to donate their deposit to charity. These effects were not statistically significant, however, but were nonetheless of economic importance to the social norm and provision of information treatments compared with the baseline. In addition, the literature review and the focus group studies clearly suggest that the default option is used when possible. 



\section{Policy Brief}

Nudging handler om at skubbe mennesker i en særlig retning - få dem til at træffe nogle særlige beslutninger - uden at fratage dem friheden til at vælge.

Nudging påvirker og former således folks adfærd i en forudsigelig retning uden at begrænsede valgmulighederne eller ændre de økonomiske incitamenter. Nudging kan erstatte eller supplere traditionelle politiske instrumenter og tilbyder således en anderledes måde at opnå politiske mål på.

På vegne af den miljøøkonomiske arbejdsgruppe (MEG) under Nordisk Ministerråd, har COWI A/S har foretaget undersøgelsen "Nudging indenfor energiforbrug, affald eller ressourceeffektivitet". Formålet med undersøgelsen er at identificere, hvordan nudging er blevet brugt i konkrete tilfælde og i eksperimenter, hvad konsekvenserne er, og hvordan nudging kan bruges som et politisk instrument.

Undersøgelsen består af to dele: et litteraturstudie foretaget af COWI og et pilotforsøg, der er udført af Mikael Knutsson, Peter Martinsson, Emil Persson og Conny Wollbrant. Pilotforsøget har undersøgt konsekvenserne af at bruge nudging til at påvirke adfærden i forbindelse med muligheden for at donere returpenge fra flasker og dåser $i$ et svensk supermarked.

I denne rapport undersøges fire typer af nudging:

- Oplysning og information.

- $\quad$ Endringer i det fysiske miljø.

- Brug af en grøn standardindstilling.

- Brug af sociale normer og løbende feedback.

Undersøgelsens overordnede resultater i forhold til de fire typer af nudging.

Samlet set viser resultaterne af litteraturstudiet og pilotforsøget, at nudging i høj grad kan anvendes til at fremme mere miljøvenlig adfærd indenfor både energiforbrug, affald og ressourceeffektivitet. Litteraturstudiet giver en indikation af, hvor ofte nudging anvendes, i hvilke lande nudging er blevet testet, samt omfanget og virkningerne af de konkrete eksempler og eksperimenter, der undersøges i litteraturstudiet. Blandt de undersøgte eksempler og eksperimenter med nudging er de fleste fundet sted på i USA. Det er dog muligt, at finde eksempler på alle fire typer af nudging i de nordiske lande. 
Litteraturstudiet viser også, at der er en overvægt af eksempler og eksperimenter, hvor nudging bruges til at påvirke adfærdsmønstre $\mathrm{i}$ forhold til energiforbrug og energieffektivitet (20 ud af de i alt 30 eksempler og eksperimenter, der gennemgås i litteraturstudiet). Nedenfor er skitseret de vigtigste resultater først i relation til typerne af nudging. Dernæst opsummeres de vigtigste resultater fra pilotforsøget og der sættes fokus på de konklusioner, der kan drages med hensyn til nudging i nordisk sammenhæng.

Undersøgelsens resultater for hver af de fire typer af nudging er skitseret nedenfor.

\section{Oplysning og information som nudging}

Oplysning og information som nudging er den mest fremherskende form for nudging.

Oplysning og information som nudging kan anvendes til at give forbrugeren adgang til faktuel og troværdig information, der skaber større gennemsigtighed og reducere kompleksiteten i valgsituationen. Der kan være tale om miljømærkning og energimærkning, som viser sig at være et effektivt nudging instrument til at fremme miljøvenlige valg (se eksempler i tabel 4-2).

Oplysning og information som nudging instrument ses også ofte i kombination med andre nudging instrumenter som for eksempel ændringer i standardindstillingen eller information baseret på sociale normer og sammenligning af forbrug mellem husstande.

Litteraturstudiet viser, at nudging i form af oplysning og information ofte anvendes med henblik på at ændre folks adfærd i forhold til energiforbrug og energieffektivitet. Litteraturstudiet viser også, at denne type nudging generelt giver gode resultater og kan påvirke energiforbruget på mellem $+1 \%$ til $-40 \%$ (se tabel $4-1$ ).

Nudging hvor forbrugeren modtager oplysninger om for eksempel husstandens energiforbrug $i$ realtid ved hjælp af individuelle intelligente målere giver en høj grad af indsigt i effekterne af det individuelle energiforbrug både miljømæssige og økonomisk. Litteraturstudiet viser, at denne type nudging kan resultere $\mathrm{i}$ betydelig reduktion af energiforbruget $\mathrm{i}$ husholdninger i spidsbelastningsperioder (morgen og aften) (se eksempel 2 og 9 i tabel $4_{-1}^{-1}$ ).

\section{Fndringer i det fysiske miljø}

Nudging gennem ændringer i det fysiske miljø viser sig at være særlig egnet til at påvirke adfærd i forbindelse med affaldssortering og genanvendelse, samt reduktion af madspild.

Litteraturstudiet har ikke fundet tilsvarende eksempler $i$ forhold til energiforbrug og energieffektivitet.

Litteraturstudiet har identificeret eksempler og eksperimenter i de nordiske lande, hvor der anvendes nudging med ændringer i det fysiske miljø. Der har været gennemført et eksperiment om at reducere madspild på 52 norske hoteller (se eksempel 25 i tabel 4-3). Eksperimentet gik ud på at reducerer størrelsen på de anvendte tallerkener, hvilket resulterede $\mathrm{i}$ at madspildet blev reduceret med næsten $20 \%$.

Et svensk eksempel handler om affaldssortering (se eksempel 26 i tabel 4-3). Her var tale om ændringer i det fysiske miljø i form af nyt affaldssorteringsudstyr, som gav bedre adskillelse til de 
forskellige affaldskilder, herunder til madaffald. Denne foranstaltning sammen med bedre information om sorteringen resulterede i en øget sortering af madaffald på mellem $44 \%$ til $49 \%$.

\section{Brug af en grøn standardindstilling som nudging}

En grøn standardindstilling kan for eksempel bruges til at fremme større udbredelsen af grøn energiforsyning. Når en forbruger skal vælge hvilken type elforsyning, der ønskes - grøn elforsyning fra vedvarende energikilder eller konventionel elforsyning baseret på fossile brændsler - er standardindstillingen sat på grøn el. Forbrugeren skal aktivt vælge den grønne el fra, og aktivt tilvælge den konventionelle elforsyning. En række eksempler og forsøg fra Tyskland viser at en meget stor procentandel af forbrugerne vælger eller forbliver på standardindstilling til fordel for grøn elforsyning (se eksempler i tabel 3-4).

Litteraturstudiet viste at denne type nudging stort set udelukkende bruges til at fremme ændringer eller reduktioner i energiforbruget og forbedring af energieffektiv adfærd. Se yderligere eksempler på brugen af en "grøn standardindstilling" til at øge energieffektiviteten og få forbrugeren til at vælge en smart grid løsning (se eksemplerne $18 \mathrm{i}$ tabel 4-2 og 12 i tabel 4-1).

Der er dog fundet ét eksempel på, at denne type nudging er brugt $\mathrm{i}$ en amerikansk universitetskantine til at fremme valget af et kødfrit måltid ved at gøre den kødfrie option til standardindstillingen (se eksempel 30 i tabel $4-3$ ).

\section{Brug af sociale normer og løbende feed-back}

Nudging ved hjælp af social normativ information og løbende feedback om for eksempel husholdningens energiforbrug og sammenligning af energiforbrug mellem husholdninger for at sætte fokus på og reducere energiforbruget er meget interessant, fordi de undersøgte eksempler viser at denne type nudging kan anvendes til at påvirke både energiforbrug, vandforbrug og affaldssortering.

En række undersøgelser i USA, Storbritannien og Irland har dokumenteret at kombinationen af information til den enkelte forbruger kombineret med social norm påvirkning i form af løbende oplysninger om det aktuelle energiforbrug kan reducere energiforbruget med op til $7 \%$ (se eksemplerne 1 og 5 til 9 i tabel $4-1$ ).

Programmet WaterSmart (USA) skønnes at have reduceret vandforbruget med $5 \%$ ved en kombination af feedback-rapporter og sammenligning mellem forbrugere (se eksempel 27, tabel 4-3).

Et eksempel fra Norge handler om affaldssortering, hvor der blev indført en afgift til at fremme affaldssortering samtidig med at der blev kommunikeret om det sociale ansvar i forhold til affaldssortering. Resultatet var en stigning i både mængden og kvaliteten af affaldssortering (se eksempel 29 i tabel 4-3). 
Litteraturgennemstudiet viste, at tre af de beskreven typer af nudging er specielt velegnet til at indgår i politik udvikling og beslutningsprocesser. Disse typer er tilvejebringelse af information og oplysninger, brug af en grøn standardindstilling, samt brug af social norm påvirkning og løbende feedback, da de alle tre har vist sig at have en stor målgruppe, der spænder fra private personer over private virksomheder til offentlige myndigheder. De har også vist sig at være i stand til at levere betydelige reduktioner $i$ energiforbruget og forbedre energieffektiviteten i en række af de eksempler og eksperimenter, som er gennemgået i litteraturstudiet. Endelig har de potentiale til at blive anvendt på andre politikområder med henblik på at reducere ressourceforbruget af for eksempel vand og affald. Nudging i form af ændringer af det fysiske miljø ses især anvendt i forbindelse med sortering og genanvendelse af affald, samt madspild. Ændringer i det fysiske miljø er ikke set anvendt som nudging, der er rettet mod forbrug af energi eller øgning af energieffektiviteten.

\section{Effekterne af nudging}

Eksemplerne og de forskellige forsøg med nudging fra litteraturstudiet viser varierende effekter fra stigninger i energiforbruget med $1 \%$ til fald i energiforbruget med op til 40\%. Energimærkning kan øge sandsynligheden for at vælge et energieffektivt produkt med op til 4,4 gange, og sættes optionen med grøn energi som standardindstilling kan det resultere i at denne grønne energi vælges i go\% af valgsituationerne. Også indenfor affald og ressourceeffektivitet ses der markante resultater så som reduktion af madspild på $20 \%$ og helt op til $135 \%$ ved at reducere størrelsen på tallerknerne.

\section{Pilotforsøget}

Pilotforsøget fandt sted $\mathrm{i}$ et supermarked, hvor forskellige former for nudging blev afprøvet på returflaske automater for at få forbrugeren til at donere returpengene for flasker og dåser til et miljøvenligt formål. De tre typer af nudges, der blev afprøvet i forsøget er: (i) tilvejebringelse af oplysninger om konsekvenserne af en donation, (ii) en ændring i det fysiske miljø, og (iii) oplysninger af normativ karakter for at fremme donation. Feltforsøget sammenligner således de relative virkninger af de tre forskellige typer af nudging for at fremme at forbrugeren donerer returpengene frem for at stikke dem i egen lomme.

Det nøje designede feltforsøg viste, at de tre former for nudging instrumenter $\mathrm{i}$ forsøget havde en positiv, men dog statistisk insignifikant effekt på folks adfærd i 
forhold til donation. Resultaterne indikerer således, at nudging der appellerer til sociale normer og giver oplysninger om donationens relation til miljøvenlig adfærd kan fremme donationer.

Desuden har litteraturstudiet og fokusgruppe undersøgelser vist, at brug af standardindstillingen har en stærk effekt på adfærd. Men der er begrænsninger med hensyn til, hvornår ændring i standardindstillingen kan bruges, da der i mange tilfælde ikke findes en naturlig standardindstilling. Resultaterne fra litteraturstudiet og resultaterne af pilotforsøget tyder på, at de undersøgte typer af nudging kan spille en vigtig rolle i den nordiske miljøpolitik, for eksempel i forhold til at ændre adfærd i forbindelse med energiforbrug, transport, affald og ressource effektivitet.

\section{Nudging i nordisk sammenhæng}

I litteraturstudiet findes en række eksempler og forsøg med nudging fra de nordiske lande og Europa, men der er flest eksempler er fra USA. Denne undersøgelse ser ikke nærmere på den eksisterende miljøregulering og undersøger ikke, hvordan nudging skal opfattes i forhold til den eksisterende miljøregulering. Eftersom affaldsområdet, ressourceeffektivitet og energiforbrug er reguleret forskelligt i USA i forhold de nordiske lande, skal der tages højde for dette, når man bygger på erfaringer fra ikkenordiske lande.

I de nordiske lande er der allerede en temmelig høj grad af miljøregulering og brug af nudging bør i høj grad designes til at passe ind og supplere den eksisterende miljøregulering. Et norsk eksempel fra affaldsområdet, hvor der blev indført en vægtafgift på de forskellige typer af affald førte til, hvad man kunne kalde for strategisk affaldssortering ved at putte andet affald ned til plastik og papiraffald. Denne adfærd kunne være en reaktioner mod yderligere miljøregulering (se eksempel 29 i tabel 17)

For at forstå hvordan nudging påvirker den enkeltes adfærd, er det af stor betydning at gennemføre større feltforsøg for at afprøve forskellige typer af nudging. Samtidig er det vigtigt at have tid nok til forsøget for at sikre en korrekt udformning, afprøvning og udførelse, især hvis et feltforsøg skal danne grundlag for policy design.

De menneskelige incitamenter og adfærd i bred forstand må forventes at være nogenlunde de samme, og hertil kommer at de fleste af eksemplerne og eksperimenter, der undersøges i litteraturstudiet - uanset om de er USA-baserede eller ej - omhandler miljømæssige temaer og udfordringer, der er fælles for de fleste lande i den udviklede del af verden. Derfor er der grund til at tro, at erfaringer fra de undersøgte eksempler og eksperimenter i denne undersøgelse kan tjene som en platform for yderligere analyse og brug af nudging i de nordiske lande. 
Litteraturstudiet viser, at der ikke findes mange undersøgelser af, hvordan forskellige typer af nudging instrumenter spiller sammen med eller supplerer andre, mere traditionelle politiske instrumenter. Resultaterne fra litteraturstudiet peger også på, at nudging i form af information i kombination med ændringer i det fysiske miljø er meget kontekstafhængige. Denne type af nudging bør derfor udvikles og testes $\mathrm{i}$ forhold til det konkrete forbrugerområde for at have en effekt på adfærden. Litteraturstudiet viser endvidere, at for at opnå succes med nudging tiltag og fremme miljøvenlig adfærd er det meget afgørende at undersøge om nudging vil modvirke den eksisterende politik. Omkostninger, køn og samspil med andre politiske instrumenter er således interessante emner for yderligere undersøgelse for at kunne designe effektiv nudging.

\section{Samlet konklusion og anbefalinger}

Samlet underbygger resultaterne af litteraturstudiet og pilotforsøget i høj grad at nudging kan anvendes til at fremme mere miljøvenlig adfærd i forhold til energiforbrug, affaldshåndtering og ressourceeffektivitet.

Flere af de typer af nudging som er undersøgt i dette projekt viser sig oplagte at anvende til at fremme affaldssortering og genanvendelse. Især ændringer i det fysiske miljø har vist gode resultater både i forhold til at øge mængden og kvaliteten af affaldssortering og genanvendelse af affald, samt reduktion af madspild. Nudging som anvender normativ information og sammenligning mellem husholdninger har vist gode resultater både i forhold til affaldssortering og vandforbrug. For valg af energikilde kan brug af en grøn standardindstilling som nudging instrument anbefales til at fremme valg af vedvarende energi. Intelligente målere er særligt interessante på grund af deres potentiale for dynamisk feedback på energiforbruget og fordi denne type nudging også kan anvendes i forhold til vandforbrug. I transportsektoren kunne der anvendes en standardindstilling, der giver mulighed for at vælge $\mathrm{CO}_{2}$ kompensation ved køb af flybilletter. Generelt viser det sig, at information om de miljømæssige konsekvenser ved en bestemt adfærd og fokus på de sociale normer ved at måle folks adfærd op imod andres adfærd er en effektiv måde at nudge på.

På baggrund af litteraturen, pilotforsøget og konklusionerne i denne undersøgelse, anbefales følgende til politiske beslutningstagere og andre relevante aktører i de nordiske lande.

Første anbefaling: Gennemgangen af nudging eksempler og eksperimenter i denne undersøgelse viser, at der ved hjælp af nudging er potentiale for at ændre folks adfærd især i forhold til energiforbrug, men også med henblik på bedre affaldshåndtering og 
øget ressourceeffektivitet. Generelt er der behov for yderligere at udforske potentialerne i nordisk sammenhæng gennem feltforsøg, der er rettet mod praksis og politikudvikling.

Anden anbefaling: Politiske beslutningstagere og andre interessenter, der er involveret i udvikling af miljøpolitiske tiltag, herunder nudging instrumenter til forskellige miljøområder bør være opmærksomme på at inddrage forsyningsvirksomhederne på nationalt plan. Forsyningsvirksomhederne har kontakten til slutbrugeren på energi-, vand- og affaldsområdet. De politiske beslutningstagere kan understøtte og skabe incitamenter for at få forsyningsvirksomhederne til at gennemføre pilotprojekter med nudging instrumenter ved for eksempel at stille værktøjer og finansiel støtte til rådighed.

Tredje anbefaling: Denne rapport kan bruges som grundlag for workshops om nudging i de nordiske lande, hvor relevante politiske beslutningstagere, offentlige myndigheder og forsyningsselskaber inviteres til at få en introduktion til nudging, samt resultaterne fra denne undersøgelse.

Fjerde anbefaling: MEG arbejdsgruppen kunne initiere og engagere sig i yderligere i undersøgelser af nudging i de nordiske lande, herunder for eksempel ved at vurdere resultaterne og effekterne af pilotprojekter og fremhæve erfaringerne på tværs af de nordiske lande. MEG arbejdsgruppen kunne mere specifikt:

- Undersøge hvordan erfaringer med nudging i forhold til energiforbrug og energieffektivitet kunne fungere som en platform til for det første at gennemføre yderligere testning i felten af forsøg med nudging på energiområdet i de nordiske lande; for det andet at undersøge hvilke potentialer der er for at overføre erfaringer med nudging fra energiområdet til andre områder som vand, affald og ressourceeffektivitet.

- Udvælge fem forsøgsområder til yderligere at udforske aspekterne omkring omkostninger, brugervenlighed, segmentering, effekt, effektivitet, kønsspørgsmål og mulige samspil med andre politiske instrumenter.

Litteraturstudiet viste, at disse aspekter ikke er undersøgt i nogen særlig grad i forhold til brug af nudging instrumenter.

- Udvælge et område af relevans på tværs af de nordiske lande, hvor traditionelle policy instrumenter ikke har nogen særlig effekt for at undersøge om nudging kunne anvendes til at skabe de ønskede ændringer. Desuden kunne der tilføjes en samfundsøkonomisk analyse af nudging instrumenternes effekter på det udvalgte område. 



\section{Appendix A References literature review}

Danish Energy Agency 2013. Brug af nudging til at øge energieffektivisering.

European Commission 2012, Policies to encourage sustainable consumption.

Löfgren, $\AA$, P. Martinsson, M. Hennlock and T. Sterner (2009) Does experience eliminate the effect of a default option? - A field experiment on $\mathrm{CO}_{2}$-offsetting for air transport, Dep. of Economics, school of Business, Economics and Law, University of Gothenburg.

Lewis, J. (2014). Evaluation of the DECC/John Lewis energy labelling trial. The Behavioural insight team.

The Behavioural insight team (2011). Behaviour Change and Energy Use. Cabinet Office.

Sanders (2015). Applying behavioural insights to charitable giving. The Behavioural insight team.

Costa \& Kahn (2010), Energy Conservation "Nudges" and Environmentalist Ideology, NBER Working Paper.

Ayres et al. (2012), Evidence from Two Large Field Experiments that Peer Comparison Feedback Can Reduce Residential Energy Usage, Journal of Law and Economic Organization.

Pichert \& Katsikopoulos (2008), Green Defaults: Information Presentation and Pro-Environmental Behaviour, Journal of Environmental Psychology.

Jessoe \& Rapson (2012), Knowledge is (Less) Power: Experimental Evidence from Residential Energy Use, NBERWorking Paper.

Brown et al. (2013), Testing the effect of defaults on the thermostat settings of OECD employees, Energy Economics

Catlin, J. \& Wang, Y. (2012). Recycling Gone Bad: When the Option to Recycle Increases Resource Consumption. Available at SSRN.

Ölander F., Thøgersen J (2014): Informing Versus Nudging in Environmental Policy, Journal of Consumer Policy. https://doi.org/10.1007/s10603-014-9256-2

Kalbekken, S., Sælen, H. (2013): 'Nudging' hotel guests to reduce food waste as a win-win environmental measure, Economics Letters. https://doi.org/10.1016/j.econlet.2013.03.019

Bernstad, A. (2014): Household food waste seperation behavior and the importance behavior and the importance of convenience. Water and Environmental Engineering, Lund University, Sweden.

Wansink, B., et al. (2013): Portion size me: plate-size induced consumption norms and win.win solutions for reducing food intake and waste. Journal of Experimental Psychology: Applied, Vol 19(4), Dec 2013, 320-332. https://doi.org/10.1037/a0035053

Lynham, J., Nitta, K., Saijo, T., Tatui, N (2015). Why does real-time information reduce energy consumption? Published by Elsevier Ltd 
Tollefsen, I. (2013). Changing up the system - a case study of how changes in waste management systems in Ullstein affects sorting behavior. Departement og Noragric, Norwegian University of Life Science.

Halpern, D., (2015). Inside the Nudging Unit: how small changes can make a big difference. Penquin Random House.

Campbell-Arvai, V., Arvai, J., Kalof, L. (2012). Motivating sustainable food choices: the role of nudges, value orientation, and information provision, Sage journals. 


\section{Appendix B References pilot experiment}

Allcott, H. 2011. Social norms and energy conservation. Journal of Public Economics 95, 10821095. https://doi.org/10.1016/j.jpubeco.2011.03.003

Allcott, H., and T. Rogers. 2014. The short-run and long-run effects of behavioral interventions: Experimental evidence from energy conservation. American Economic Review 104, 3003-3037. https://doi.org/10.1257/aer.104.10.3003

Bénabou, R., and J. Tirole. 2006. Incentives and Prosocial Behavior. American Economic Review 96, 1652-78. https://doi.org/10.1257/aer.96.5.1652

Cartwright, E., 2014. Behavioural Economics. Routledge Abingdon.

Cialdini, R. 2003. Crafting normative messages to protect the environment. Current Directions in Psychological Science 12. 105-109. https://doi.org/10.1111/1467-8721.01242

Costa, M., and M. Kahn. 2013. Energy conservation "nudges" and environmentalist ideology: Evidence from a randomized residential electricity field experiment. Journal of the European Economic Association 11. 680-702. https://doi.org/10.1111/jeea.12011

DellaVigna, S, 2009. Psychology and economics: Evidence from the field, Journal of Economic Literature 47, 315-372. https://doi.org/10.1257/jel.47.2.315

Duflo, E., Glennerster, R., and M. Kremer, M.. 2008. Using Randomization in Development Economics Research: A Toolkit, in: Handbook of Development Economics, edited by Paul Schultz and John Strauss, 3895-3962. North Holland.

Egebark and M. Ekström. 2016. Can indifference make the world greener? Journal of Environmental Economics and Management 76, 1-13. https://doi.org/10.1016/j.jeem.2015.11.004

Fellner, G., R. Sausgruber, and C. Traxler. 2013. Testing Enforcement Strategies in the Field: Threat, Moral Appeal and Social Information. Journal of the European Economic Association 11, 634-66o. https://doi.org/10.1111/jeea.12013

Goldberg, M., and K. Gunasti. 2007. Creating an Environment in which Youths are Encouraged to Eat a Healthier Diet. Journal of Public Policy \& Marketing 26, 162-181.

https://doi.org/10.1509/jppm.26.2.162

Hagman, W., D. Andersson, D. Västfjäll, and G. Tinghög. 2015. Public Views on Policies Involving Nudges. Review of Philosophy and Psychology 6, 439-453. https://doi.org/10.1007/s13164015-0263-2

Harrison, G., and J. List. 2004. Field Experiments. Journal of Economic Literature 42, 1013-1059. https://doi.org/10.1257/0022051043004577

House of Lords, 2011. Behaviour Change, The House of Lords, London.

Johnson, E.J. and D. Goldstein. 2003. Do defaults save lives?, Science 302, 1338-1339.

https://doi.org/10.1126/science.1091721 
Kallbekken, S:, and H. Sælen. 2013. Nudging Hotel Guests to Reduce Food Waste as a Win-Win Environmental Measure. Economics Letters 119, 325-327. https://doi.org/10.1016/j.econ-

let.2013.03.019

Kallbekken, S., H. Sælen, and E. Hermansen. 2013. Bridging the energy Efficiency Gap: A Field Experiment on Lifetime Energy Costs and Household Appliances. Journal of Consumer Policy 36, 1-16. https://doi.org/10.1007/s10603-012-9211-z

Knutsson, M., P. Martinsson, E. Persson and C. Wollbrant. 2016. Nudging prosocial behavior: Relative effects of three intervention classes. Working Paper, University of Gothenburg.

Löfgren, Å., P. Martinsson, M. Hennlock, and T. Sterner. 2012. Are Experienced People Affected by a Pre-set Default Option-Results from a Field Experiment. Journal of Environmental Economics and Management 63,66-72. https://doi.org/10.1016/j.jeem.2011.06.002

Madrian, B.C. and D.F. Shea. 2001. The power of suggestion: Inertia in 401(k) participation and savings behavior, Quarterly Journal of Economics 116, 1149-1187.

https://doi.org/10.1162/003355301753265543

Pruckner, G., and R. Sausgruber. 2013. Honesty on the Streets: A Field Study on Newspaper Purchasing. Journal of the European Economic Association 11, 661-679.

https://doi.org/10.1111/jeea.12016

Thaler, R. H., and Sunstein, C. 2008. Nudge: Improving Decisions about Health, Wealth, and Happiness. New Haven, CT: Yale University Press.

van Bavel, R., B. Herrmann, G. Esposito and A. Proestakis (2013), Applying Behavioural Sciences to EU Policy-making. JRC Scientific and policy reports, EUR26033EN.

Vi-skogen. 2016. http://www.viskogen.se/English/ (accessed: March, 2016). 
Nordic Council of Ministers

Ved Stranden 18

DK-1061 Copenhagen K

www.norden.org

\section{Nudging and pro-environmental behaviour}

This study explores how nudging instruments are used to encourage environmentally friendly behavior within energy consumption, waste management and resource efficiency. The study results provide very interesting examples of nudging resulting in reduced energy consumption in households due to providing real-time information, peer comparison and the use of green defaults, as well as increased and improved quality of waste sorting and reduction of food waste through changes in the physical environment. The study also presents the results of a field experiment examining how nudges can encourage consumers in a super market to choose to donate the deposit refunded from reverse-vending machines for beverage containers to an environment friendly cause. Overall, the findings of this study provide a strong case for using nudging instruments to promote more environmentally friendly behavior. 